\title{
THERMAL STRESSES IN STEEL CAR WHEELS.
}

\author{
By George K. Burgess and G. Willard Quick.
}

\begin{abstract}
.
Nineteen steel wheels were tested by using the method described for testing chilled iron car wheels in the laboratory under conditions approximating those encountered in service caused by heavy brake application. ${ }^{1}$ The rims of the wheels were heated to a temperature of $380^{\circ} \mathrm{C}$. by passing an electric current through a band of soft steel encircling the wheel. The resulting stresses were calculated from strain-gage measurements after correcting for thermal expansion. Eight worn wheels and II new wheels, representing five types of manufacture, were tested and none failed in the tests. As a result of heating the rim, the hub moved with respect to the rim, inducing tensile stress on the face and compression on the back near the hub. Near the rim the stresses were in compression on the face and in tension on the back except for worn wheels, where no stress was induced on the face. The maximum surface stresses developed were slightly above the yield point of the material, producing a permanent set for first tests on new wheels, while no set resulted from tests on old wheels or in succeeding tests on new wheels. Data are also given on the properties of the wheels tested.
\end{abstract}

\section{CONTENTS.}

Page

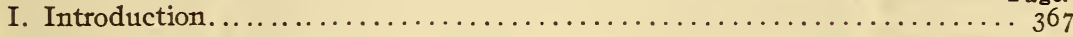

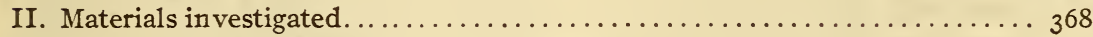

I. Wheels and methods of manufacture ................... 368

III. Tests. . . . . . . . . . . . . . . . . . . . . . . . . . . . . . ${ }_{369}$

I. Procedure for special thermal stress tests................. 369

2. Auxiliary tests.................................... 37 I

(a) Linear thermal expansion........................ $37 \mathrm{I}$

(b) Tensile properties............................ $37^{2}$

(c) Chemical composition.......................... 373

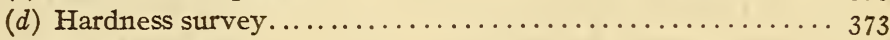

IV. Results of thermal stress tests............................... 374

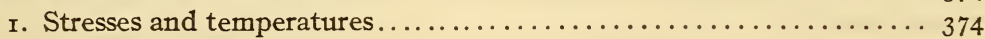

V. Summary and conclusions................................. 377

\section{INTRODUCTION.}

In I920 a conference of representatives of several manufacturers and purchasers of steel car wheels was held at the Bureau of Standards to discuss plans for conducting an investigation of thermal stresses developed in the plates of steel wheels caused by heating the tread in a manner approximating service conditions.

\footnotetext{
1 B. S. Tech. Paper No. 209: Thermal Stresses in Chilled Iron Car Wheels.
} 
Experienced railway men say that the tread becomes heated to a dull red on long, heavy grades by the application of brake shoes. It was agreed at the conference that it would be of general interest and of value to the steel-wheel industry to investigate these stresses, the plan being to conduct the tests in a manner identical with the procedure followed in the investigation of thermal stresses in chilled-iron car wheels with some additional tests on steel wheels at as high a temperature as possible with the special equipment and including a survey of the stresses induced in the back of the plate.

Other problems present themselves in connection with the subject of stress caused by brake application-as the effect of speed, shoe pressure, and length of application in producing thermal stresses. At Purdue University an investigation of these problems, with the wheels revolving while a brake shoe is held in contact with the treads, is in progress. In the investigation at this bureau the manner in which thermal stresses build up in wheels, the magnitude, nature, and location of stresses have been studied.

\section{MATERIALS INVESTIGATED.}

\section{WHEELS AND METHODS OF MANUFACTURE.}

The wheels used in the tests were 33 -inch steel car wheels, representing the product of 6 different plants and representative of 5 methods of manufacture in current use. Eight worn wheels ${ }^{2}$ representing the product of 4 different plants, 2 new wheels furnished by each of 4 different manufacturers, I new wheel and 2 "freak" wheels from another mill, made a total of 19 wheels upon which I or more series of measurements were made. The manufacturers cooperating have been designated by the letters $\mathrm{U}, \mathrm{V}, \mathrm{W}, \mathrm{X}, \mathrm{Y}$, and $\mathrm{Z}$. Table I shows more clearly the status of the wheels used, including a brief description of the methods of manufacture.

Figures 2 to 7 , inclusive, are drawings of sections of the wheels of each manufacturer. Figures $8 \mathrm{a}$ and gà are photographs of a rolled-steel wheel and a cast-steel wheel, respectively.

\footnotetext{
${ }^{2}$ Furnished by the Pennsylvania Railroad.
} 
TABLE 1.-Wheels Tested.

\begin{tabular}{|c|c|c|c|c|}
\hline \multirow{2}{*}{ Manufacturer. } & \multicolumn{3}{|c|}{ Number of wheels. } & \multirow{2}{*}{ Method of manufacture. } \\
\hline & New. & Old. & Total. & \\
\hline $\begin{array}{l}\text { U.... } \\
\text { V... }\end{array}$ & $\frac{2}{2}$ & $\begin{array}{l}2 \\
2\end{array}$ & $\begin{array}{l}4 \\
4\end{array}$ & $\begin{array}{l}\text { Forged and rolled from an individual ingot. } \\
22 \text { by } 22 \text { inch ingot rolled into } 15 \text {-inch round, which } \\
\text { is sheared into blanks. The blanks are forged }\end{array}$ \\
\hline w. & & 2 & 2 & $\begin{array}{l}\text { and rolled nto wheess. } \\
\text { Ingot rolled into plates from which biscuits are cut. }\end{array}$ \\
\hline $\mathbf{x}$. & 2 & 2 & 4 & $\begin{array}{l}\text { Cast in a revolving mold. First part of pour is high } \\
\text { in Mn, forming the tread, while low-carbon stee }\end{array}$ \\
\hline$\frac{\mathbf{Y}}{\mathbf{Z} . .}$ & 12 & & $\begin{array}{l}2 \\
3\end{array}$ & $\begin{array}{l}\text { Same procedure as manufacturer } \mathrm{V} \text {. } \\
90 \text {-inch, } 12 \text {-sided, fited ingot with sand-lined sink } \\
\text { head is cut cold into blocks of proper weight. These } \\
\text { blociss are heated in a continuous furnace, after } \\
\text { which they are forged and rolled into wheeis. }\end{array}$ \\
\hline Total.. & 11 & 28 & 19 & \\
\hline
\end{tabular}

1 One standard design, one thin plate, and one with straight plate.

2 Furnished by Pennsylvania Railroad.

\section{TESTS.}

\section{PROCEDURE FOR SPECIAL THERMAL STRESS TESTS.}

The equipment and test methods used, described below, are the same in part as given in the paper on Thermal Stresses in Chilled Iron Car Wheels.

In the special thermal stress tests the wheel was mounted on a hollow water-cooled 6-inch axle. The axle in turn rested upon cast-iron and concrete supports, so that the bottom of the wheel was 2 feet 8 inches above the floor. A soft-steel resistor $3 \frac{1}{2}$ inches in width and one-fourth inch in thickness was placed on the tread of the wheel, but insulated from it by a thin sheet of perforated asbestos, and an alternating current of $\mathrm{I}, 000$ to $\mathrm{I}, 500$ amperes at I 5 to 30 volts from a $30-k v a$. transformer was passed through it. As the wheel was in an upright position and remained stationary throughout the test, it was readily possible to take such observations as necessary. Figure I shows the arrangement of this apparatus. It was found possible to bring the resistor itself to a red heat within 5 to ro minutes. Undue radiation of heat into the air was prevented by the use of asbestos covering. The tread of the wheel attained a maximum temperature of approximately $380^{\circ} \mathrm{C} .\left(716^{\circ} \mathrm{F}\right.$.) in each run.

In order to interpret the results of these tests, it was necessary to determine satisfactorily the distribution of temperature in the wheel from tread to hub. Copper-constantan thermocouples of No. 30 American gage wire were used-seven couples along a vertical radius at approximately 2 -inch intervals and seven others 
similarly located along the horizontal radius. Readings were taken along both radii for the purpose of obtaining duplicate results. Two other thermocouples were inserted into the tread of the wheel. Thus, four couples, one at the gap in the resistor, were placed at equidistant points in the tread of the wheel and assurance given that uniformity of tread temperatures was attained. The 16 copper-constantan thermocouples can be seen in Figure I, extending from the wheel to the overhead supports and then down to the potentiometer on the transformer table.

A 2-inch Berry strain gage was used for measuring the deformations. Five sets of readings were taken at $\mathrm{r}$-inch intervals on the vertical and horizontal radii on both the face and back of the plate. On some wheels it was possible to take six sets of straingage readings. It will be observed that these readings were taken over considerable area, this being the only manner of satisfactorily determining the location of the point of maximum stress. A better understanding of the location of the points at which strain gage and thermocouple readings were taken can be obtained from Figure. ro.

It was necessary to take a survey of the stresses only along the radii of the wheels, since preliminary measurements had shown that the tangential stresses were of a compressive nature and of relatively small magnitude.

Identical rates of power input were maintained for each test in order to obtain comparative results. It was necessary to increase the power input near the end of the test to attain the desired tread temperature in a comparatively short time.

Table 4 in Bureau of Standards Technical Paper No. 209 shows the schedule of power supplied to the resistor for all the tests. The energy applied per minute during the different periods of the test was as follows:

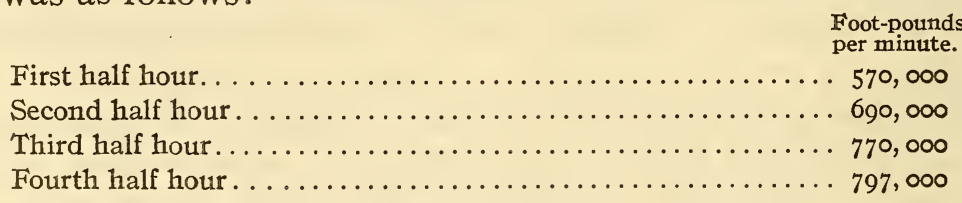

Table 5 of the same paper gives an approximate comparison between the work performed on the test wheel and the energy required to hold a train at a constant speed on descending grades.

However, the actual test conditions were more severe than these figures indicate on account of the difference in the heat dissipation in the two cases. In these tests the resistor completely encircled the wheel and was thermally insulated to drive the heat 
into the wheel. Under these conditions a larger percentage of the energy supplied to the resistor entered the wheel than would be the case when the same wheel is subjected to brake application, as occurs in service, due to the fact that part of the energy spent by friction between the shoe and wheel goes to heating the brake shoe and thence by radiation to the air, and, further, the shoe only bears on a small part of the circumference, thus allowing the heat in the uncovered part of the tread to radiate directly into the air instead of entering the wheel.

Readings were taken of the temperature, strain, and power input at regular intervals, a strain-gage reading of the cold wheel being also taken before the test was started. When the desired tread temperature was reached, the power was shut off and the asbestos covering on the resistor removed to permit more rapid dissipation of the heat. Temperature and strain gage readings were also taken during cooling and after the wheel was at room temperature.

The elongation as determined by the strain gage is attributable to two causes: (I) An elongation due to the thermal expansion of metal, and (2) elongation caused by the strain due to the temperature gradient from tread to hub of the wheel. By knowing the coefficient of expansion and the temperature rise it was possible to calculate the thermal expansion. By deducting the elongation due to this expansion from the total elongation the elongation due to stress alone was determined. The relation between stress and strain on samples actually taken from the wheels made it possible to convert the strain readings into stress values. ${ }^{3}$

\section{AUXILIARY TESTS.}

The following auxiliary tests were made in order to interpret and supplement the results of the special thermal stress tests.

(a) Linear Thermal Expansion.-The coefficient of expansion of specimens taken from one wheel of every manufacturer was determined for the range 20 to $400^{\circ} \mathrm{C}$. These specimens from the rolled steel wheels were $30 \mathrm{~cm}$ long and I cm square. ${ }^{4}$ The specimens from the cast-steel wheel (manufacturer $\mathrm{X}$ ) were small bullet-shaped samples I $\mathrm{cm}$ long with a tripod base. One sample was taken from the rim, one from the plate, and one from

\footnotetext{
3 The accuracy of determinations for tests are discussed in the paper Thermal Stresses in Chilled Iron Wheels, and the conclusion is that the probable error throughout the major range of the stress measurements is $\pm 3,000 \mathrm{lbs}$./in. ${ }^{2}$

The method used for the determination of expansion of these samples is described in B. S. Sci. Paper No. 352 , p. 390 . These determinations were made in the expansion laboratory under the direction of Dr. W. H. Souder.
} 
the hub. These samples were tested by a special optical method. ${ }^{5}$ The differences between samples from rim, plate, and hub were so slight that the results were not affected by them for the temperature range used and a composite equation was obtained. The samples from the wheels of manufacturers cooperating showed a unit expansion represented by the following equations:

$$
\begin{aligned}
& \text { Manufacturer } \mathrm{U} \frac{\Delta l}{l}=10.83 \times \mathrm{IO}^{-6}{ }_{t}+7.53 \times \mathrm{IO}^{-9}{ }^{2} \\
& \mathrm{~V} \frac{\Delta l}{l}=10.67 \times \mathrm{I0}^{-6}{ }_{t}+7.65 \times \mathrm{IO}^{-9}{ }_{t}^{2} \\
& \mathrm{~W} \frac{\Delta l}{l}=\mathrm{I} \mathrm{I} .37 \times \mathrm{IO}^{-6} t+7.00 \times \mathrm{IO}^{-9,9} \\
& \mathrm{X} \frac{\Delta l}{l}=\mathrm{I} \mathrm{I} .60 \times 10^{-6}{ }_{t}+8.79 \times 10^{-8,}{ }_{t}^{2} \\
& \mathrm{Y} \frac{\Delta l}{l}=10.67 \times \mathrm{IO}^{-6} t+7.83 \times \mathrm{IO}^{-9} t^{2} \\
& Z \frac{\Delta l}{l}=11.04 \times 1^{-6} t+6.70 \times 10^{-8} t^{2}
\end{aligned}
$$

The above equations were computed by the method of least squares and apply for the temperature range between $o$ and $400^{\circ} \mathrm{C}$.

Table 2 shows that the unit expansion of the different steels as calculated from the above equations for different temperature ranges agrees well within the precision required.

TABLE 2.-Comparison of Expansion Equations.

\begin{tabular}{l|r|r|r|r|r|r}
\hline \multirow{2}{*}{ Temperature range $\left({ }^{\circ} \mathrm{C}.\right)}$. & \multicolumn{5}{|c|}{ Total expansion, in inches per inch calculated by equations, for steels } \\
from manufacturers-
\end{tabular}

(b) Tensile Properties. - The tensile properties of the steels were determined on two 8-inch gage-length specimens taken from the plates of one rolled-steel wheel of manufacturers $U, V, W, Y$, and $\mathrm{Z}$, while 2-inch gage-length specimens were taken from a wheel of manufacturer $\mathrm{X}$ because, due to the corrugated plate, it

${ }^{5}$ The Use of the Interferometer in the Measurement of Small Dilatations or Differential Dilations. C. G. Peters, Jour. of the Washington Acad. of Sci., 9, No. 1o, May 19, Igrg. 
was impossible to obtain 8-inch samples. All samples were pulled on a 50,000-pound Amsler machine, a Ewing extensometer being used. Figure II shows the composite stress-strain curves obtained from these tensile tests. Table 3 gives the averaged results of the tensile tests.

TABLE 3.-Tensile Properties.

\begin{tabular}{|c|c|c|c|c|c|c|c|}
\hline Manufacturer. & $\begin{array}{c}\text { Pro- } \\
\text { portional } \\
\text { limit. }\end{array}$ & Yield point. & $\begin{array}{l}\text { U1timate } \\
\text { strength. }\end{array}$ & $\begin{array}{l}\text { Modulus of } \\
\text { elasticity. }\end{array}$ & $\begin{array}{l}\text { Elongation } \\
\text { in } 2 \text { inches. }\end{array}$ & $\begin{array}{l}\text { Elongation } \\
\text { in } 8 \text { inches. }\end{array}$ & $\begin{array}{l}\text { Reduction } \\
\text { of area. }\end{array}$ \\
\hline 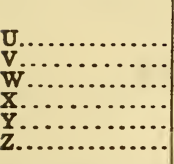 & $\begin{array}{r}\text { Lbs./in. } .^{2} \\
46,100 \\
49,500 \\
38,400 \\
45,200 \\
47,000 \\
48,000\end{array}$ & $\begin{array}{r}\text { Lbs./in. }{ }^{2} \\
52,100 \\
\ldots \ldots \ldots \\
43,400 \\
50,700 \\
53,300 \\
61,900\end{array}$ & $\begin{array}{r}\text { Lbs./in. }{ }^{2} \\
123,300 \\
119,500 \\
107,000 \\
85,000 \\
122,000 \\
130,200\end{array}$ & $\begin{array}{l}\text { Lbs./in. }{ }^{2} \\
29,000,000 \\
23,900,000 \\
29,600,000 \\
30,500,000 \\
29,600,000 \\
29,000,000\end{array}$ & $\begin{array}{r}\text { Per cent. } \\
13.5 \\
12.5 \\
13.8 \\
14.5 \\
11.2 \\
11.2\end{array}$ & $\begin{array}{r}\text { Per cent. } \\
9.8 \\
7.9 \\
10.5 \\
9.0 \\
9.0 \\
7.8\end{array}$ & $\begin{array}{r}\text { Per cent. } \\
14.1 \\
13.6 \\
14.8 \\
23.6 \\
10.5 \\
13.9\end{array}$ \\
\hline
\end{tabular}

(c) Chemical Composition.-The chemical composition of one wheel submitted by each manufacturer was determined. Drillings for these analyses were taken from the plates of the rolledsteel wheels of manufacturers $U, V, W, Y$, and $Z$ about midway between the hub and the rim. For the cast-steel wheel of varying composition ro drillings were taken across the whole diameter. Figure 12 shows the positions from which the drillings were taken. The results of the analyses are given in Table 4 .

TABLE 4.-Chemical Composition of Wheels.

\begin{tabular}{|c|c|c|c|c|c|c|}
\hline \multirow{2}{*}{ Manufacturer. } & \multirow{2}{*}{$\begin{array}{l}\text { Position } \\
\text { number. }\end{array}$} & \multicolumn{5}{|c|}{ Chemical Analysis. } \\
\hline & & Carbon. & Sulphur. & Phosphorus. & Manganese. & Silicon. \\
\hline 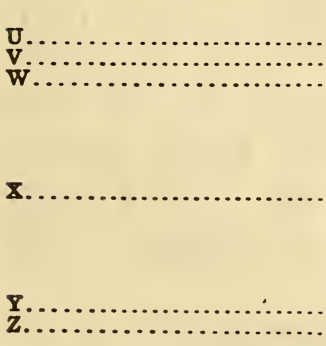 & $\begin{array}{r}3 \\
3 \\
3 \\
1 \\
2 \\
3 \\
4 \\
5 \\
6 \\
7 \\
8 \\
9 \\
10 \\
3 \\
3\end{array}$ & $\begin{array}{r}\text { Per cent. } \\
0.67 \\
.73 \\
.66 \\
.32 \\
.26 \\
.25 \\
.18 \\
.20 \\
.25 \\
.20 \\
.24 \\
.21 \\
.30 \\
.77 \\
.75\end{array}$ & $\begin{array}{r}\text { Per cent. } \\
0.019 \\
.015 \\
.014 \\
.025 \\
.019 \\
.022 \\
.018 \\
.015 \\
.022 \\
.022 \\
.022 \\
.021 \\
.023 \\
.032 \\
.026\end{array}$ & $\begin{array}{r}\text { Per cent. } \\
0.029 \\
.028 \\
.027 \\
.023 \\
.022 \\
.022 \\
.019 \\
.021 \\
.021 \\
.020 \\
.023 \\
.020 \\
.023 \\
.032 \\
.019\end{array}$ & $\begin{array}{r}\text { Per cent. } \\
0.77 \\
.73 \\
.67 \\
1.60 \\
1.15 \\
.76 \\
.72 \\
.69 \\
.67 \\
.68 \\
.92 \\
.86 \\
1.66 \\
.69 \\
.66\end{array}$ & $\begin{array}{r}\text { Per cent. } \\
0.19 \\
.21 \\
.17 \\
.29 \\
.29 \\
.28 \\
.28 \\
.24 \\
.28 \\
.28 \\
.28 \\
.27 \\
.29 \\
.16 \\
.25\end{array}$ \\
\hline
\end{tabular}

(d) Hardness Survey.-A survey of radial sections of the rolled and cast type of wheel was made for Brinell hardness. Impressions were made at $\mathrm{I}$-inch intervals along the radius, the first one being about one-eighth inch from the rim. There was very little variation in hardness along the radial section of the $24838^{\circ}-23-2$ 
rolled wheels, but for the cast wheel the hardness varied widely from rim to hub. These wheels were hardest near the rim and softer in toward the hub, with a position quite deficient in hardness at the middle of the rim where shrinkage holes occurred. Figure $\mathrm{I} 3$ shows the variations in hardness from the rim toward the hub for rolled and cast wheels. These curves were obtained from surveys made on two rolled wheels and one cast wheel. Figures $8 \mathrm{~b}$ and $9 \mathrm{~b}$ are photographs of radial cross sections of a rolled and cast wheel, respectively, showing the spongy section of the cast wheel where the Brinell values were low.

\section{RESULTS OF THERMAL STRESS TESTS.}

\section{STRESSES AND TEMPERATURES.}

As was predicted by representatives of steel wheel manufacturers, none of the wheels tested failed from the stresses developed during the tests.

For the new rolled-steel wheels of regular design the maximum stresses developed on the face of the plate were in tension near the hub and in compression near the rim, while on the back of the plate the conditions were reversed. These stresses are produced by expansion of the rim, causing the hub to move relative to the rim, as indicated in Figure I4. The relative movement of the hub was determined by holding a 3 -foot straightedge firmly against the machined face of the hub and measuring the distance from the flange with a steel scale. The average movement of the hubs of the standard-design wheels submitted by the various manufacturers (U, V, W, X, Y, and Z) was as follows: $\mathrm{U}, 0.08$ inch; V, 0.07 inch; W, 0.09 inch; X, 0.07 inch; $\mathrm{Y}, 0.09$ inch; and $\mathrm{Z}, \mathrm{O}$.10 inch. The movement of the hub of one of the wheels used for the high-temperature run (manufacturer V) was 0.09 inch; that of the thin plate and straight plate wheels (manufacturer Z) were o.Io and 0.04 inch, respectively. The average maximum temperature difference between thermocouples $\mathrm{I}$ and 7 was $289^{\circ} \mathrm{C}$. $\left(55^{\circ} \mathrm{F}\right.$. $)$.

Of the two special wheels furnished by manufacturer $Z$ the one with a thinner plate developed stresses similar, but of somewhat greater magnitude, to those developed in the wheels of regular design. The tread of this wheel was also lighter than that of the regular wheels. Figure 6 is a sectional drawing of this special wheel. The stresses developed in the special wheel with the straight plate were in tension on both the face and the back of 
the plate. The stresses were greatest at position $D$ on the face of the plate. On the back of the plate the greatest stresses were at position $A$, near the rim. Figure ro shows these positions along the radii. Figure 7 is a sectional drawing of this wheel.

For the worn rolled wheels tested, in which considerable metal had been worn from the tread, as shown in Figure I4, the stresses developed on the face of the plate were in tension near the hub and gradually diminished to practically zero at the rim, while on the back of the plate the stresses were of about the same nature and magnitude as for the new wheels. The neutral axis on the face of the old wheels is shifted from position $C$ out toward the rim, as shown by curves on Figures 16, 19, and 21. Figures 15, I 8 , and 30 are curves of average stresses on the face of new wheels, and these show the neutral axis to be near the center of the radius. This difference for worn wheels is a result of service and may be due to the work on the tread, static loads, impacts, the thinner tread, or a combination of any of these factors.

In the tests on the cast-steel wheels the stresses were more complicated because of the nature of the plate, which is of a corrugated design. Figures 23 to 27 , inclusive, show stress-time curves for different positions along the radius on both face and back of the plate on the crests and in the hollows for both old and new cast-steel wheels. Figures 15 to 35, inclusive, show stress-time curves for different positions along the radii of all wheels. These curves are the average stresses of the horizontal and vertical radii of all wheels of different manufacturers of the same type. Thus, curve $C$, Figure I $_{5}$, is the average of horizontal and vertical stresses for all determinations in tests on all new wheels of manufacturer $U$ at positions $C$ and $I$, which can be located on Figure io.

From the first test on new wheels a permanent set was observed on the surfaces of the plates at positions of maximum stress, indicating that the material was strained beyond the yield point at the points on the surface. Table 5 gives the average deformations on the vertical and horizontal radii for each position $A^{\prime}$, $A, B$, etc., with the corresponding maximum stresses. It is seen from this table that the maximum tensile stresses at positions $E$ and, in some cases, at positions $D$ for manufacturers $\mathrm{U}, \mathrm{V}, \mathrm{Y}$, and $Z$, were above the yield point, and the corresponding permanent deformations were greatest at these points. The maximum compressive stresses approximated the yield point of the material, 
and the permanent deformations are smaller than those corresponding to the maximum tensile stresses. At intermediate points along the radii where the stresses were not as high as the yield point the deformations are relatively small.

The results from the first tests on the new wheels of manufacturer $\mathrm{X}$ were rather irregular, and since this cast wheel had a corrugated plate it is hard to account for these results. At position $E$ the stress and corresponding permanent deformations were greatest, being similar in this respect to the rolled-steel wheels of regular design. At some other places along the radii the stresses and deformations are not consistent.

TABLE 5.-Maximum Stress and Permanent Deformations on Face of New Wheels. After First Test.

\begin{tabular}{|c|c|c|c|c|c|c|}
\hline \multirow[b]{2}{*}{ Manufacturer. } & \multirow[b]{2}{*}{ 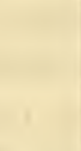 } & \multicolumn{2}{|c|}{ Tensile properties. } & \multirow{2}{*}{$\begin{array}{l}\text { Posi- } \\
\text { tions. }\end{array}$} & \multirow{2}{*}{$\begin{array}{l}\text { Maximum } \\
\text { stress. }\end{array}$} & \multirow{2}{*}{$\begin{array}{l}\text { Perma- } \\
\text { nent def- } \\
\text { ormation. }\end{array}$} \\
\hline & & $\begin{array}{l}\text { Propor- } \\
\text { tional } \\
\text { limit. }\end{array}$ & $\begin{array}{l}\text { Yield } \\
\text { point. }\end{array}$ & & & \\
\hline U............... & th & $\begin{array}{l}\text { Lbs./in.2 } \\
46,100\end{array}$ & $\begin{array}{l}\text { Lbs./in. }{ }^{2} \\
52,100\end{array}$ & $\begin{array}{l}\mathbf{A}^{\prime} \\
\mathbf{A} \\
\mathbf{B} \\
\mathbf{C} \\
\mathbf{D} \\
\mathbf{E}\end{array}$ & $\begin{array}{r}\text { Lbs./in. }{ }^{2} \\
-53,200 \\
-8,700 \\
+26,100 \\
+50,700 \\
+63,000 \\
+65,600\end{array}$ & 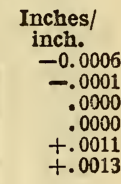 \\
\hline 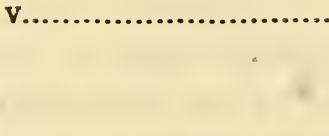 & & 49,500 & & $\begin{array}{l}\mathbf{A}^{\prime} \\
\mathbf{A} \\
\mathbf{B} \\
\mathbf{C} \\
\mathbf{D} \\
\mathbf{E}\end{array}$ & $\begin{array}{r}-58,100 \\
-51,600 \\
+8,700 \\
+58,100 \\
+66,200\end{array}$ & $\begin{array}{l}-.0008 \\
-.0006 \\
+.0002 \\
+.0005 \\
+.0016\end{array}$ \\
\hline 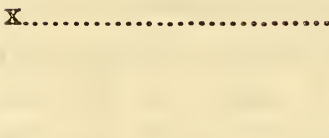 & & 45,200 & 50,700 & $\begin{array}{l}\mathbf{A}^{\prime} \\
\mathbf{A} \\
\mathbf{B} \\
\mathbf{C} \\
\mathbf{D} \\
\mathbf{E}\end{array}$ & $\begin{array}{r}+7,600 \\
-12,100 \\
-21,300 \\
-21,300 \\
+6,100 \\
+51,000\end{array}$ & $\begin{array}{l}+.0001 \\
-.0001 \\
=.0006 \\
=.0010 \\
-.0004 \\
+.0029\end{array}$ \\
\hline Y & & 47,000 & 53,300 & $\begin{array}{l}\mathbf{A}^{\prime} \\
\mathbf{A} \\
\mathbf{B} \\
\mathbf{C} \\
\mathbf{D} \\
\mathbf{E}\end{array}$ & $\begin{array}{r}-48,300 \\
-8,900 \\
+29,600 \\
+53,400 \\
+57,600\end{array}$ & $\begin{array}{l}-.0004 \\
-.0001 \\
-.0001 \\
+.0002 \\
+.0006\end{array}$ \\
\hline $\mathrm{z}$ (regular design)................. & ......... & 48,000 & 61,900 & $\begin{array}{l}\mathbf{A}^{\prime} \\
\mathbf{A} \\
\mathbf{B} \\
\mathbf{C} \\
\mathbf{D} \\
\mathbf{E}\end{array}$ & $\begin{array}{r}-52,700 \\
-24,600 \\
+7,300 \\
+46,000 \\
+68,800\end{array}$ & $\begin{array}{l}-.0003 \\
-.0001 \\
=.0001 \\
-.0002 \\
+.0010\end{array}$ \\
\hline $\mathbf{Z}$ (thin plate) $\ldots \ldots \ldots \ldots \ldots \ldots$ & 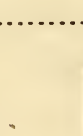 & 48,000 & 61,900 & $\begin{array}{l}\mathbf{A}^{\prime} \\
\mathbf{A} \\
\mathbf{B} \\
\mathbf{C} \\
\mathbf{D} \\
\mathbf{E}\end{array}$ & $\begin{array}{l}-57,300 \\
-26,100 \\
+23,200 \\
+58,400 \\
+67,200\end{array}$ & $\begin{array}{l}+.0001 \\
+.0001 \\
+.0001 \\
+.0001 \\
+.0004\end{array}$ \\
\hline$Z$ (straight plate) $\ldots \ldots \ldots \ldots$ & & 48,000 & 61,900 & $\begin{array}{l}\mathbf{A}^{\prime} \\
\mathbf{A} \\
\mathbf{B} \\
\mathbf{C} \\
\mathbf{D} \\
\mathbf{E}\end{array}$ & $\begin{array}{r}+36,200 \\
+57,400 \\
+65,000 \\
+62,800 \\
+50,800\end{array}$ & $\begin{array}{l}-.0001 \\
+.0001 \\
+.0008 \\
+.0006 \\
.0000\end{array}$ \\
\hline
\end{tabular}


In the tests on both the special thin-plate and straight-plate wheels of manufacturer $Z$ the permanent deformations of appreciable magnitude occurred at positions where the maximum stress approximated or exceeded the yield point of the steel. The smaller permanent deformations at points where the stress is not as high as the yield point may be caused by the relieving of strains in the thermal test that were caused by the manufacturing process, but it seems evident that the maximum deformations are in part, at least, the result of stresses above the yield point of the steel.

In succeeding tests on new wheels and in all tests on old wheels there were no permanent deformations noted, showing that the stress is not increased beyond the yield point on repeated heating. The tests on the old wheels indicate that the heating they had been subjected to in service stressed them beyond the yield point on the surface of the plates at certain positions and relieved any manufacturing strains, rendering these wheels in the same condition as new wheels after the first thermal test in this investigation.

The maximum tread temperature ordinarily reached about $380^{\circ} \mathrm{C}$. in 90 minutes. Special tests were made on two new rolled wheels and one new cast wheel at the highest temperature attainable with the equipment, about $500^{\circ} \mathrm{C}$. The time to reach this temperature was about 60 minutes longer than was required to reach $380^{\circ} \mathrm{C}$. in the regular tests, but the stresses developed were no greater. The greater strain in the plate appears to be offset by greater expansion due to the higher temperature, thus giving a flat, stress-time curve between 380 and $500^{\circ} \mathrm{C}$. Figures 36 and 37 are stress-time curves showing the behavior of the stresses on the face and back of the plate, respectively, of a new rolled wheel of manufacturer A during a test at higher temperature. The results of the other tests at higher temperature, mentioned above, were of the same nature as those given in Figures 36 and 37 .

Figure 38 shows time-temperature curves for the different thermocouple positions for a typical series of observations.

\section{SUMMARY AND CONCLUSIONS.}

Nineteen 33 -inch steel wheels have been tested in a manner approximating conditions encountered in service through long applications of brakes on heavy grades. In the tests the rims 
of the wheels were heated electrically, and the hubs were kept cool by passing tap water through the hollow axle upon which the wheels were mounted. The maximum tread temperature was about $380^{\circ} \mathrm{C}$. in regular tests, and in the special tests a maximum temperature of about $500^{\circ} \mathrm{C}$. was attained. From observations of the deformations in the plates of the wheels the stresses have been computed after correcting for thermal expansion. Six manufacturers furnished new wheels representing five different methods of manufacture, as follows: From the individual ingot, the long ingot cut into blanks, the $\mathrm{r} 2$-sided fluted ingot cut into blanks, the ingot rolled into a slab from which biscuits were cut, and the cast-steel wheel with high manganese tread. Eight old wheels manufactured by four of the companies were also tested. The interesting features revealed in the tests may be summarized as follows:

I. None of the wheels failed.

2. When the rim is heated, the hub moves with respect to the rim, inducing stresses in the plate which, for the first test on new wheels, are in tension near the hub and in compression near the rim on the face, while on the back of the plate the stresses for the same positions near hub and rim are about equal in magnitude but reverse in nature to those on the face.

3. For worn wheels the stresses are of the same character, except near the rim on the face, where very little stress is found. This difference is due to the shifting of the neutral axis on the face from the center of the radius toward the rim and is caused by conditions of service.

4. The maximum stresses were slightly above the yield point of the material as determined in tensile tests.

5. A permanent set was apparent only for new wheels on the first tests. For old wheels and in succeeding tests on new wheels there was no set apparent, showing that the stresses above the yield point were not increased by repeated heating, and that the old wheels had been rendered, by service, in a condition similar to that of new wheels after the first thermal test.

6. For forged wheels the character and magnitude of the stresses developed in the surface of the plate are little affected by the method of manufacture. The stresses developed in the cast-steel wheels were, because of the corrugated plate, more complicated than those in the rolled wheels. 
The bureau is undertaking a study of the residual stresses in steel car wheels from the manufacturing processes. In this work sections are being sawed from the wheels and stresses so relieved will be calculated from deformations measured with a strain gage.

The authors are indebted to those manufacturers who generously furnished wheels and made valuable suggestions regarding tests and to S. J. Rosenberg, who assisted with the laboratory tests, calculations, and made the drawings.

WASHINGTON, October 26, 1922.

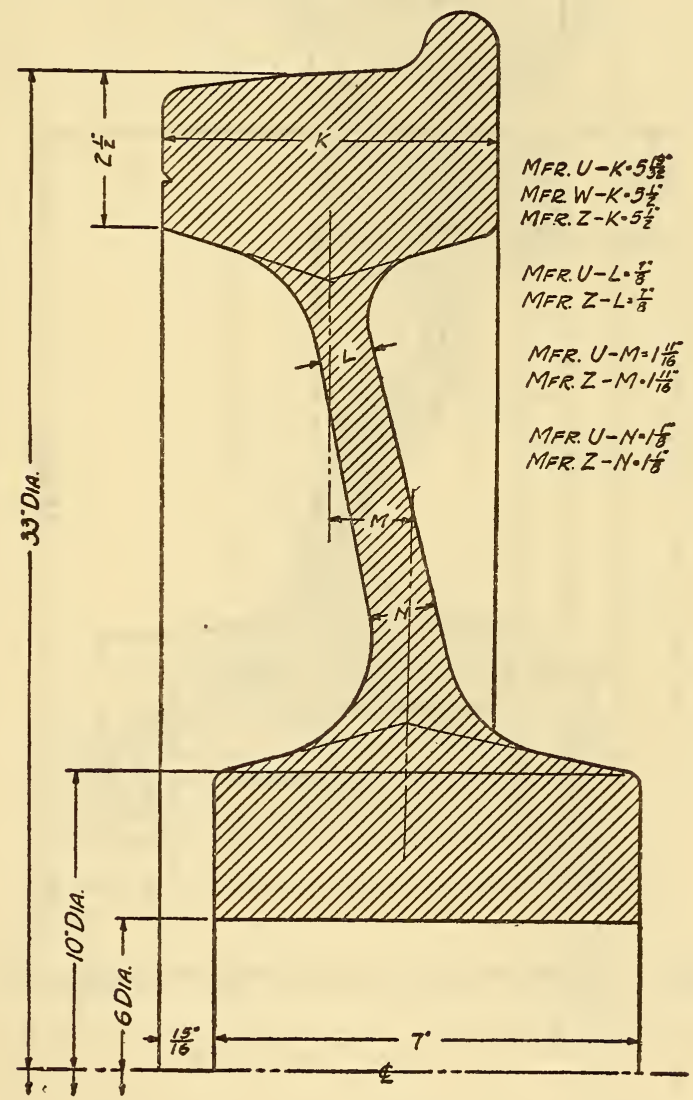

FIG. 2.-Radial sections of standard wheels of manufacturers $U, W$, and $Z$. 


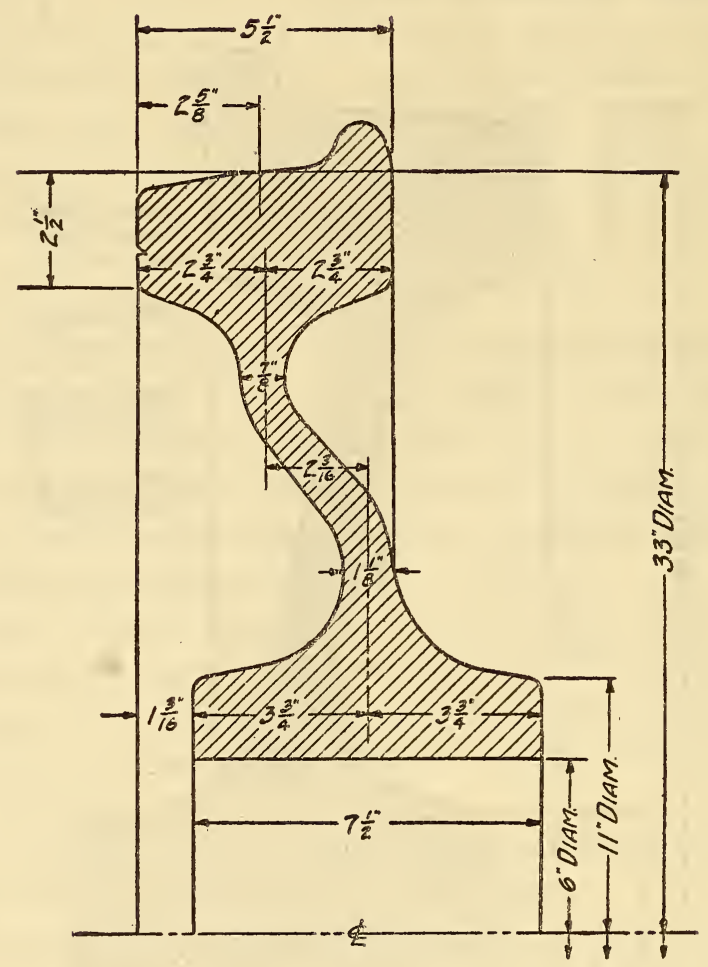

FIG. 3.-Radial section of standard wheel of manufacturer $V$. 


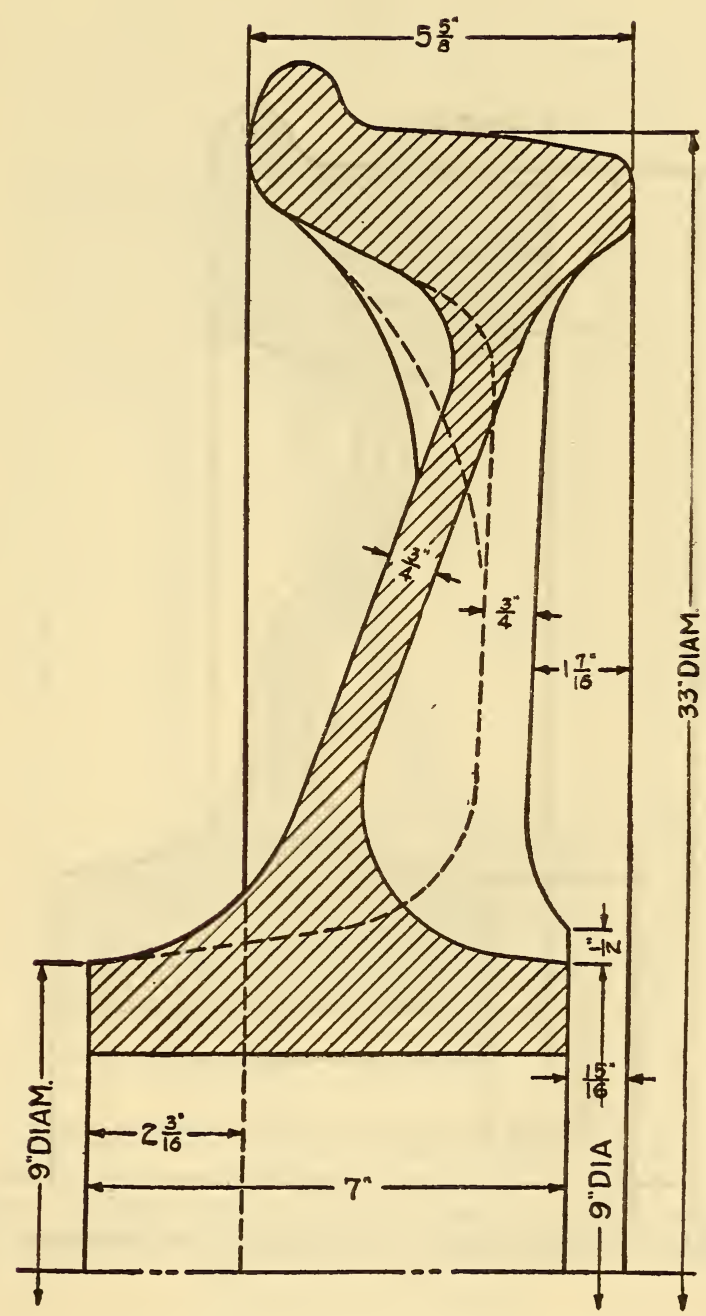

FIG. 4.-Radial section of standard wheel of manufacturer $X$. $24838^{\circ}-23-3$ 


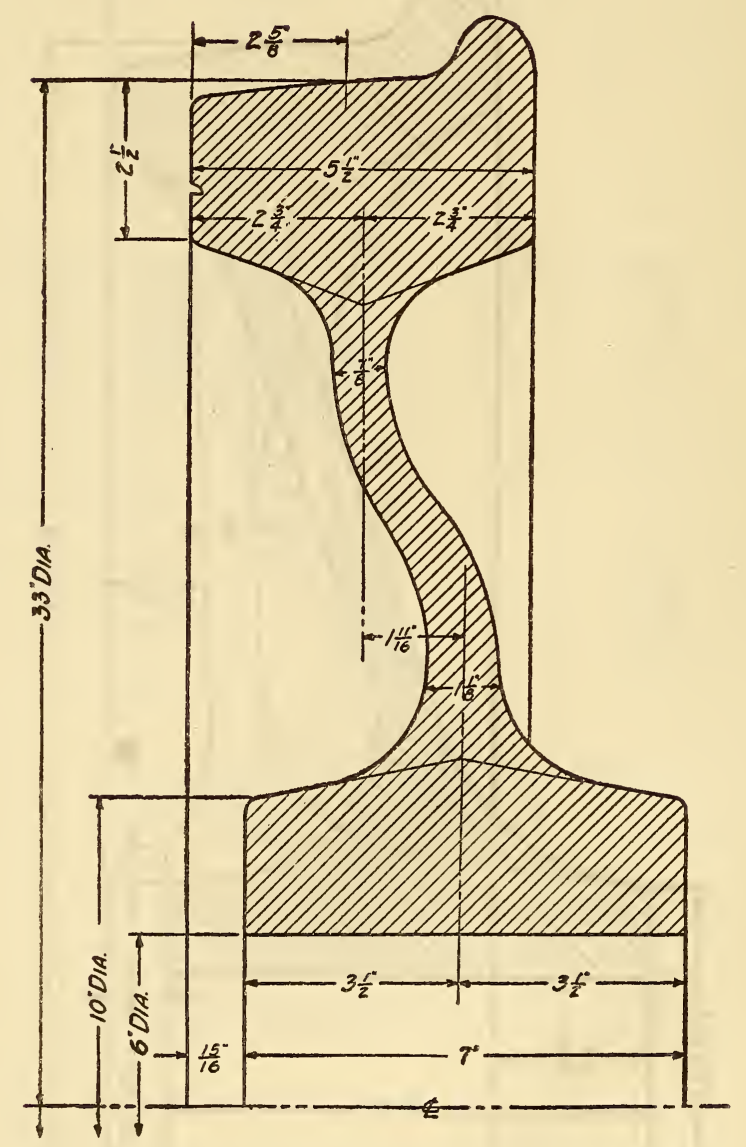

FIG. 5.-Radial section of standard wheel of manufacturer $Y$. 


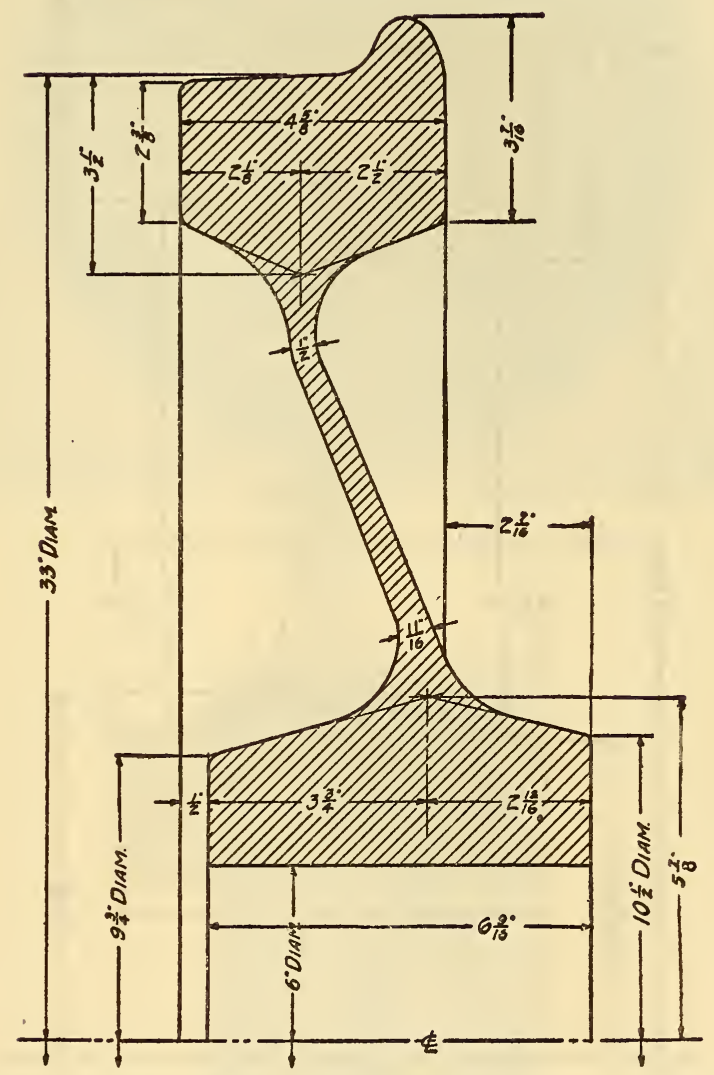

Fig. 6.-Radial section of thin-plate wheel of manufacturer $Z$. 


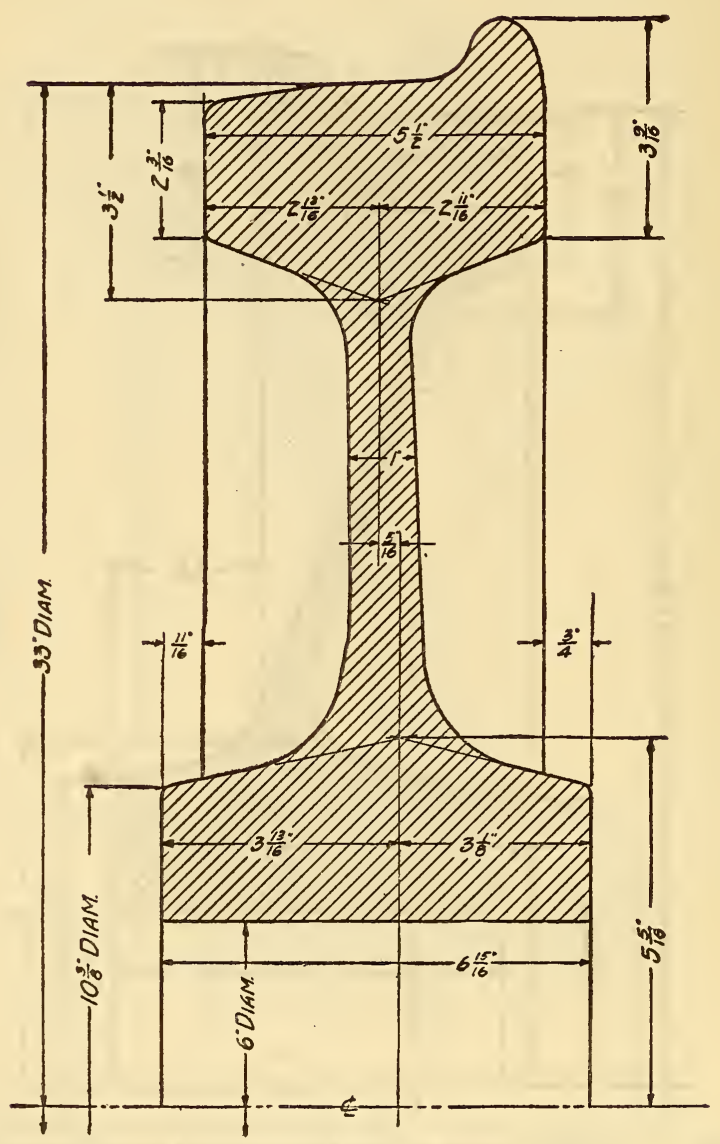

FIG. 7.-Radial section of straight-plate wheel of manufacturer $Z$. 
Technologic Papers of the Bureau of Standards.

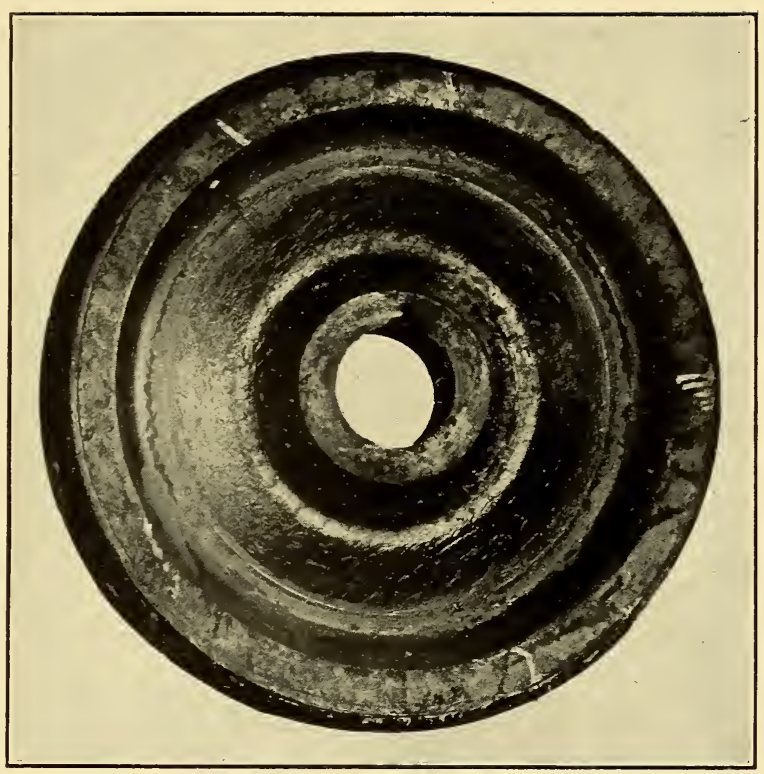

FIG. 8a.-Photograph of a rolled-steel wheel.

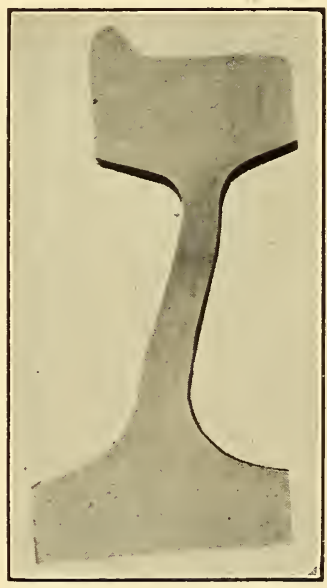

FIG. 8b.-Photograph of a section of a rolled-steel wheel. 
Technologic Papers of the Bureau of Standards.

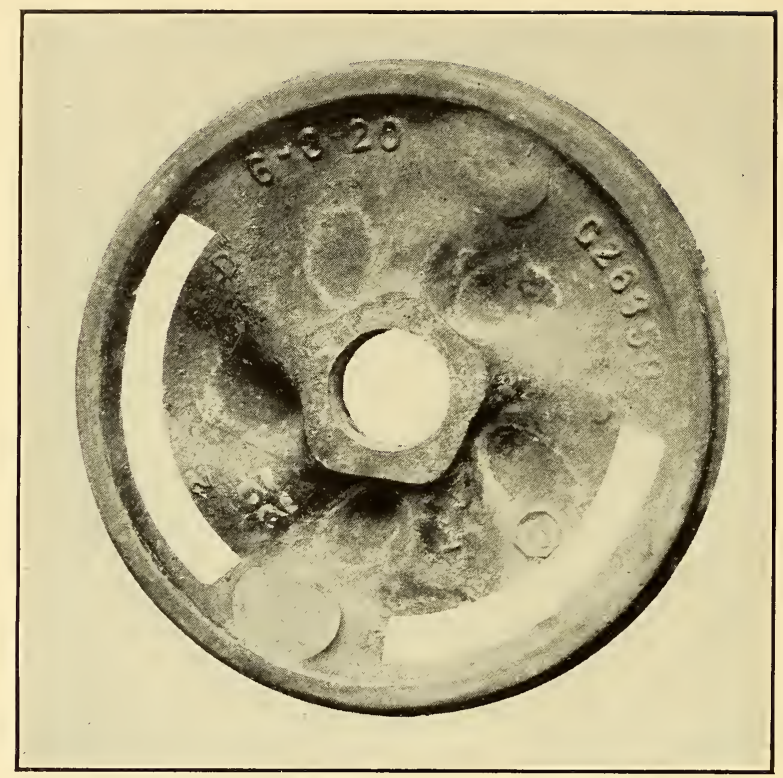

Fig. 9a.-Photograph of a cast-steel wheel.

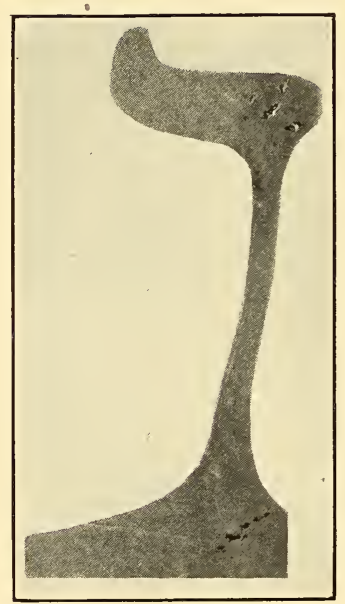

FIG. 9b.-Photograph of a section of a cast-steel wheel showing shrinkage holes. 


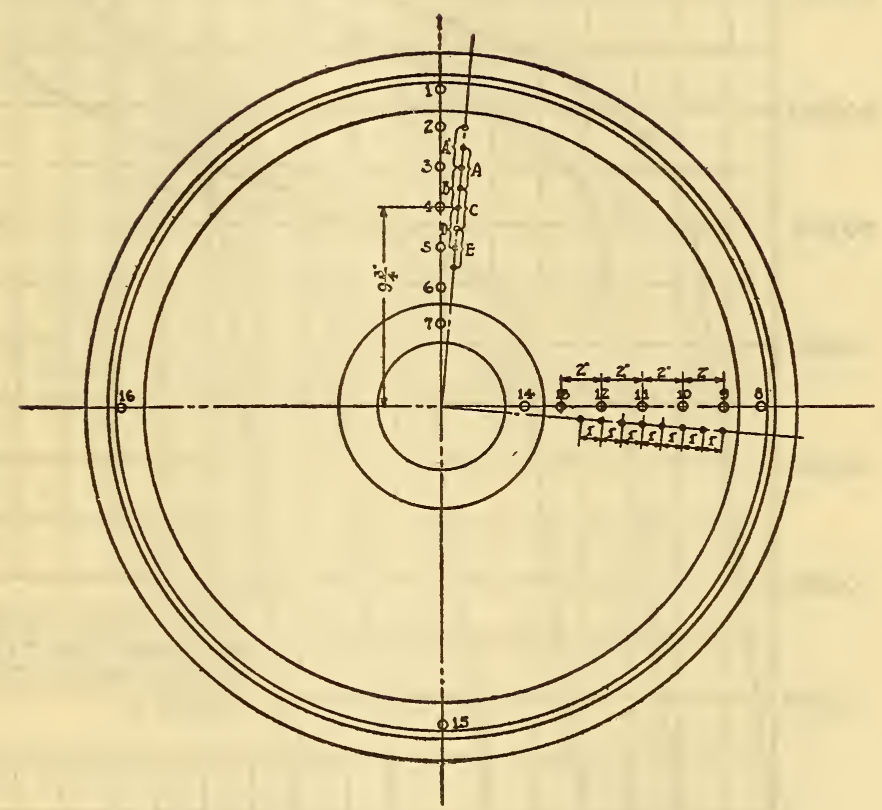

Fig. I0.-Locations of thermocouple and strain-gage holes. 


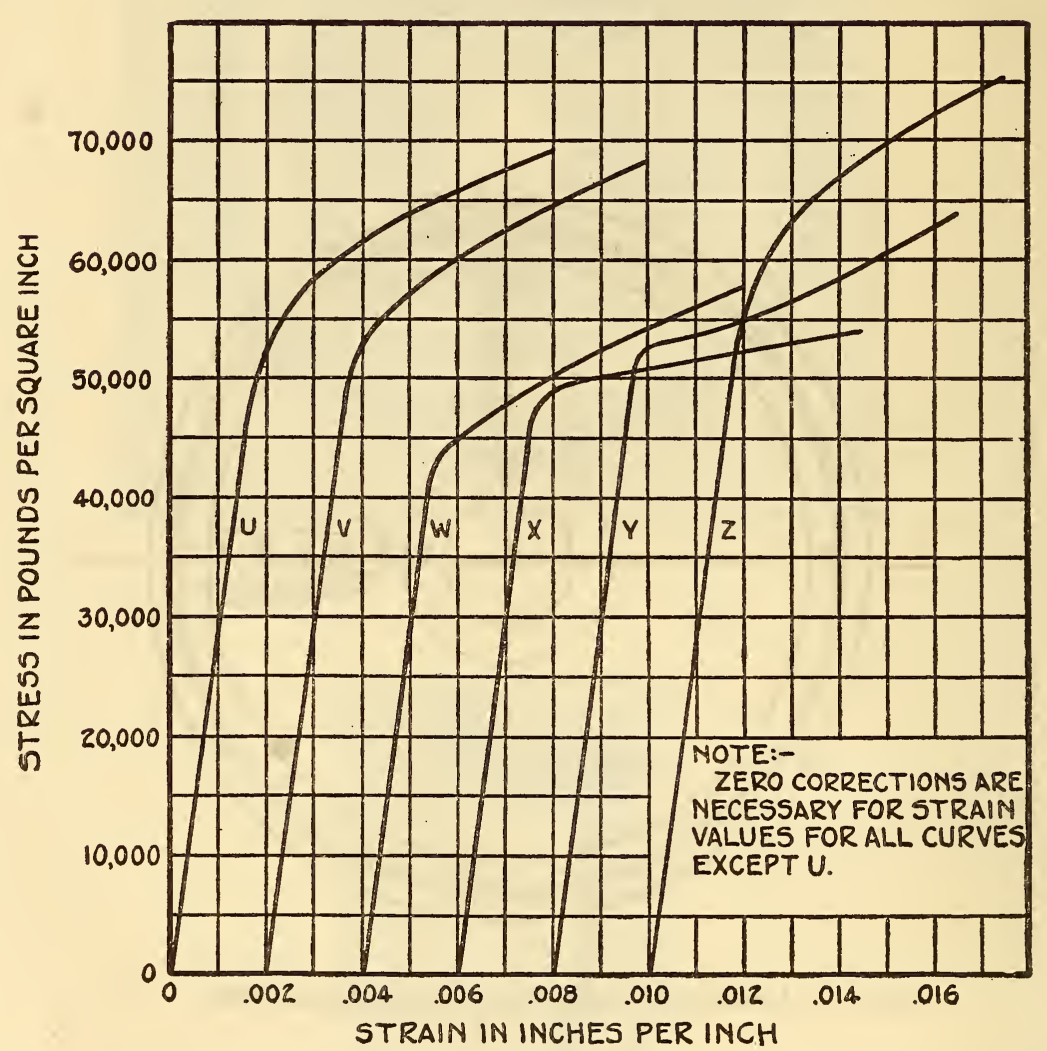

FIG. II. - Typical stress-strain curves obtained from tensile tests on samples of steel from wheels of the six manufacturers. 


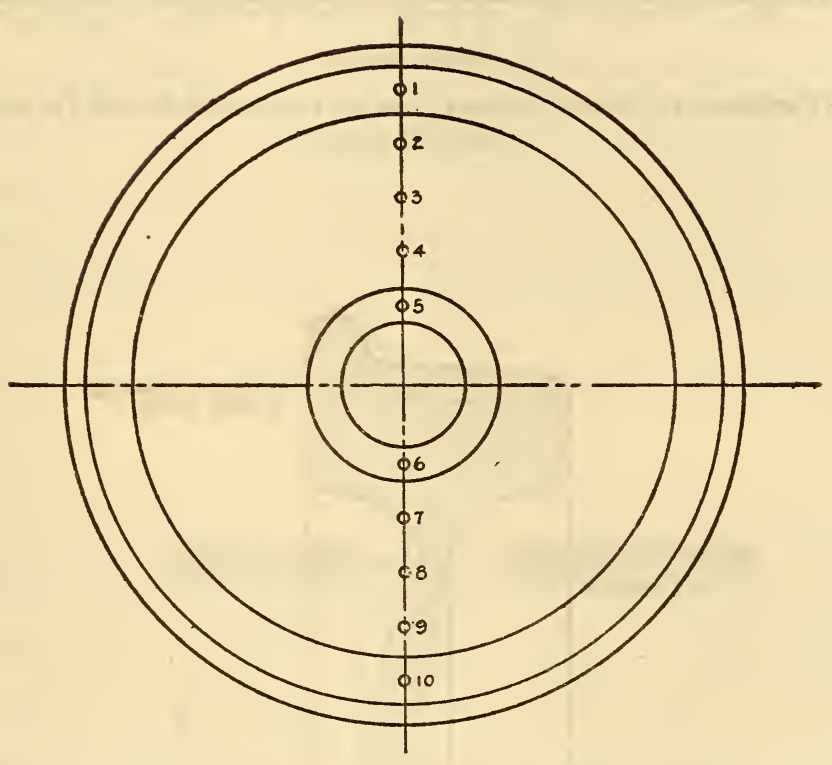

FIG. 12.-Position of drillings from the cast-steel wheel for chemical analysis. 


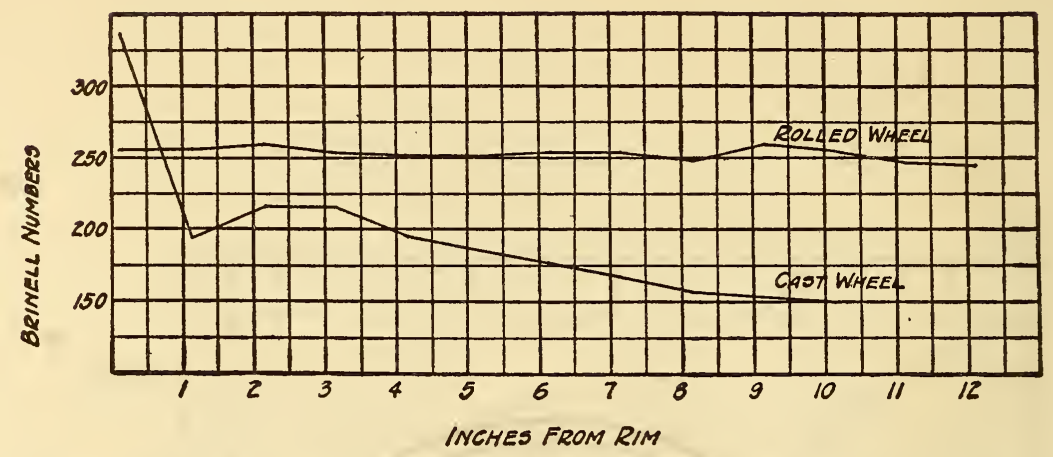

Fig. 13.-Variations in Brinell hardness from the run toward the hub for the rolled and cast steel wheels.

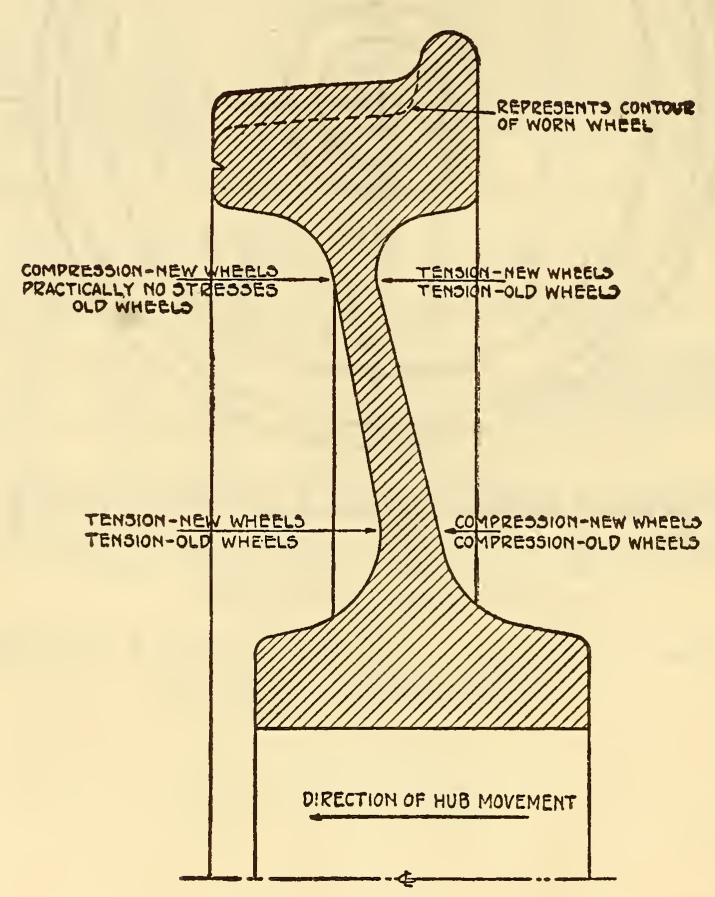

Fig. 14.-Cross section showing nature and location of the maximum surface stresses induced in new and worn wheels. 


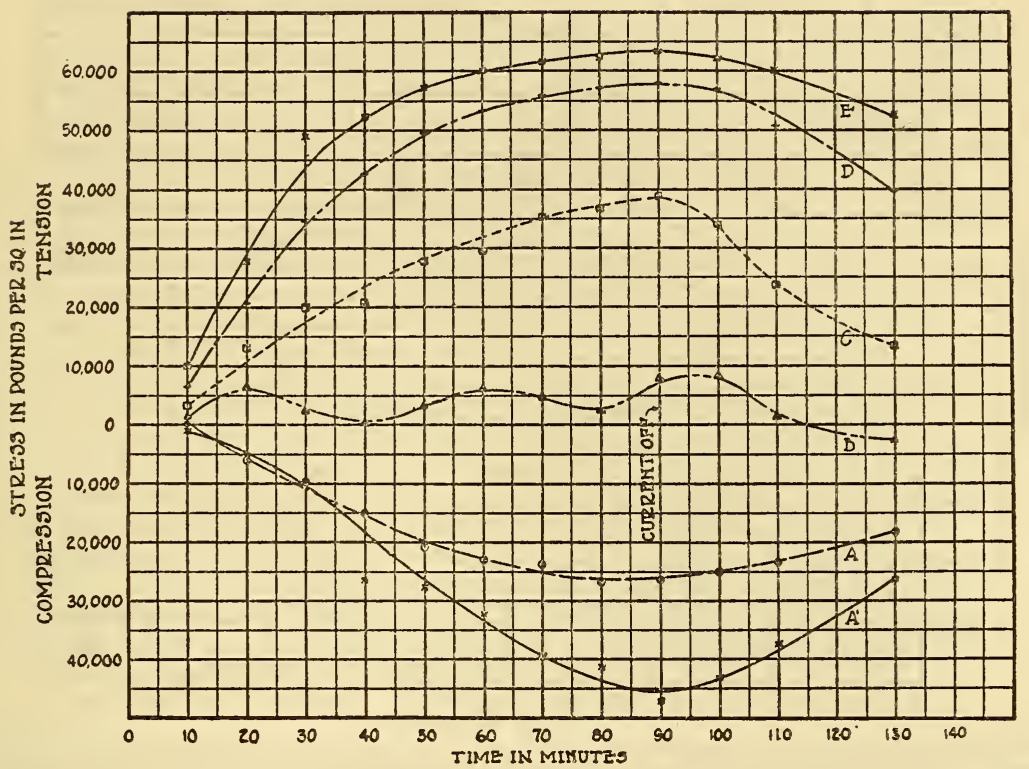

FIG. 15.-Stress-time curves showing average stresses developed on face of all new wheels of manufacturer $U$.

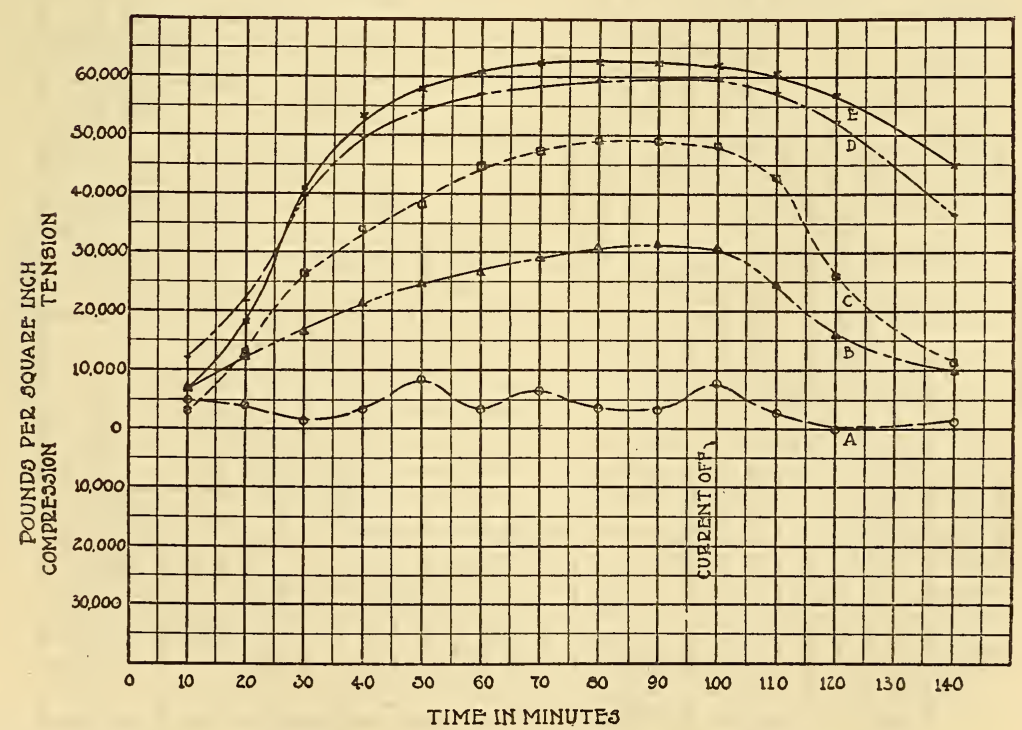

FIG. I6.-Stress-time curves showing average stresses developed on face of all worn wheels of manufacturer $U$. 


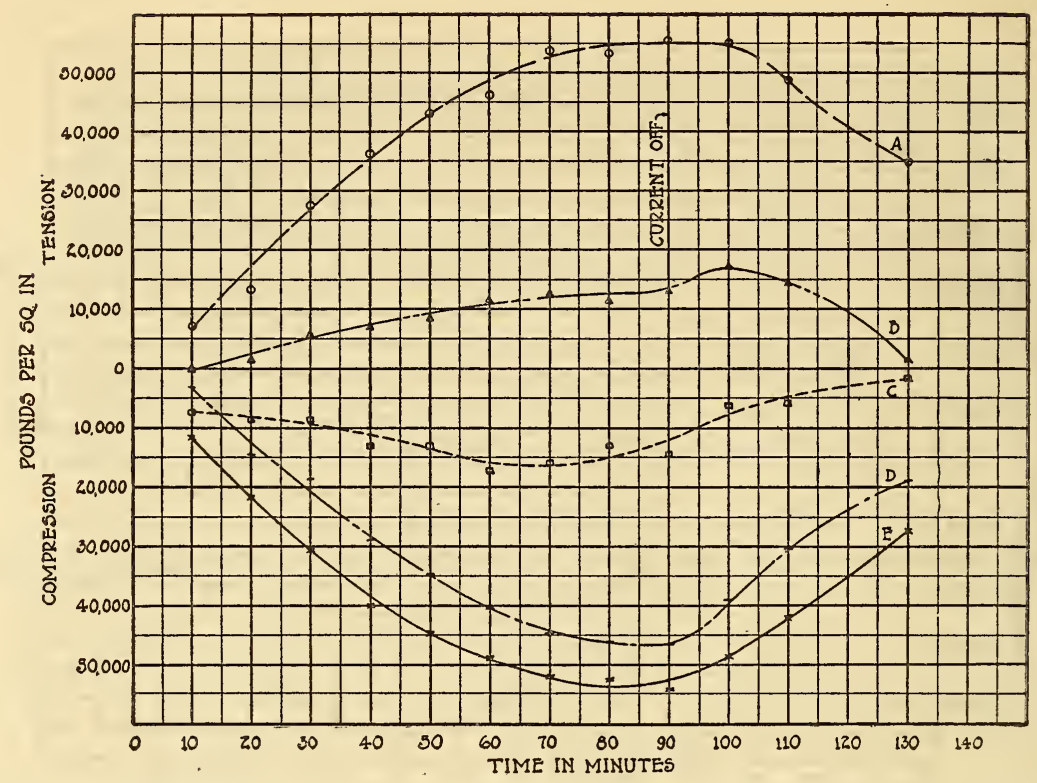

FIG. I7.-Stress-time curves showing average stresses developed on back of a new wheel of manufacturer $U$.

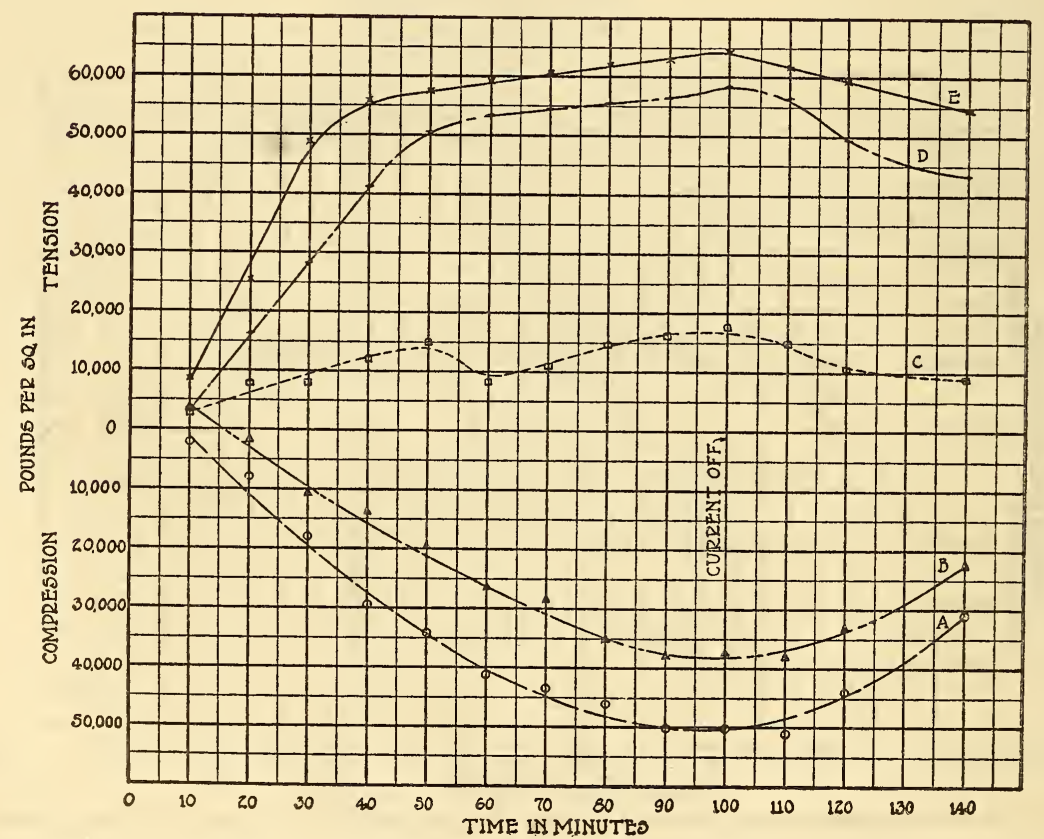

FIG. I8.-Stress-time curves showing average stresses developed on face of all new wheels of manufacturer $V$. 


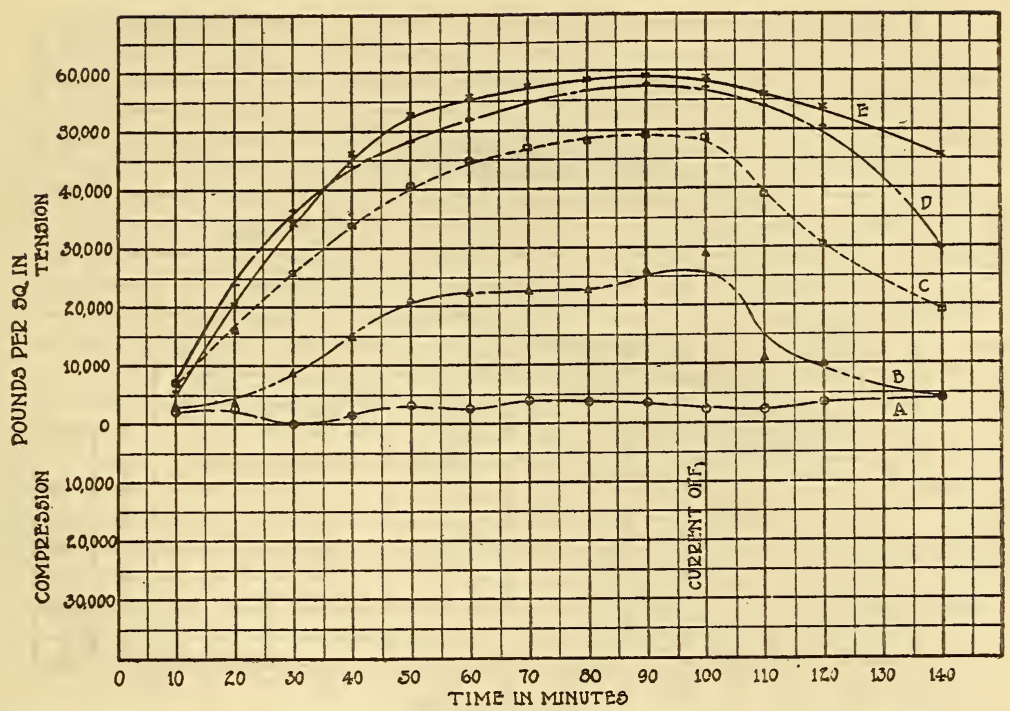

FiG. 19.-Stress-time curves showing average stresses developed on face of all worn wheels of manufacturer $V$.

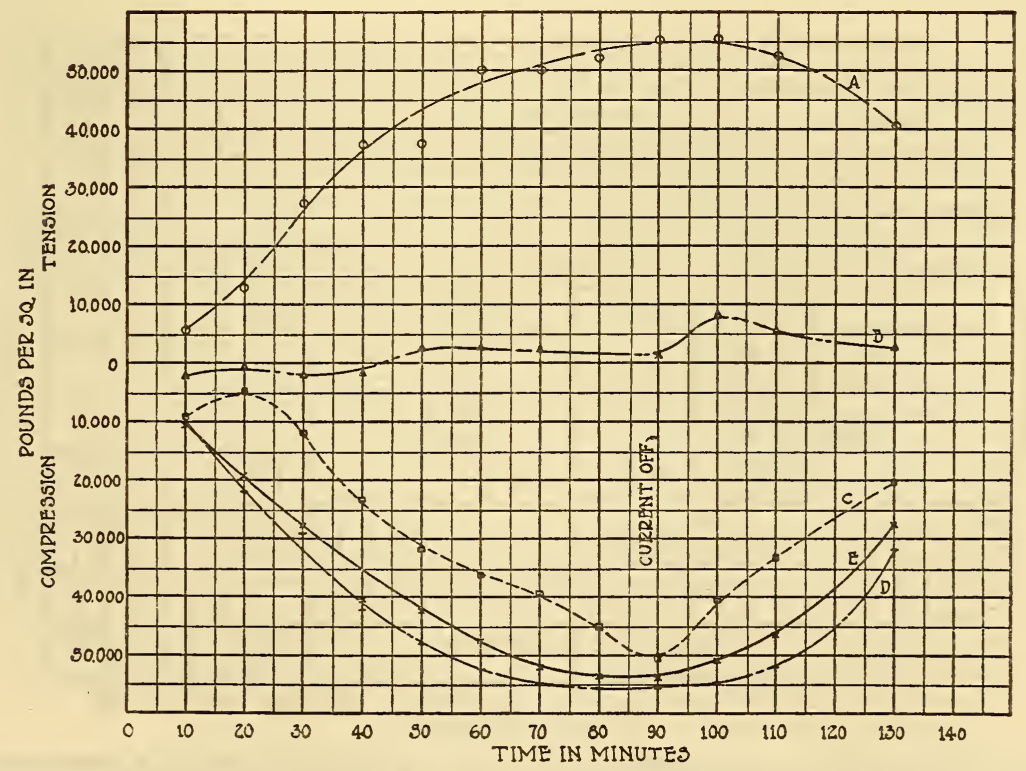

FIG. 20.-Stress-time curves showing average stresses developed on back of a new wheel of manufacturer $V$. 


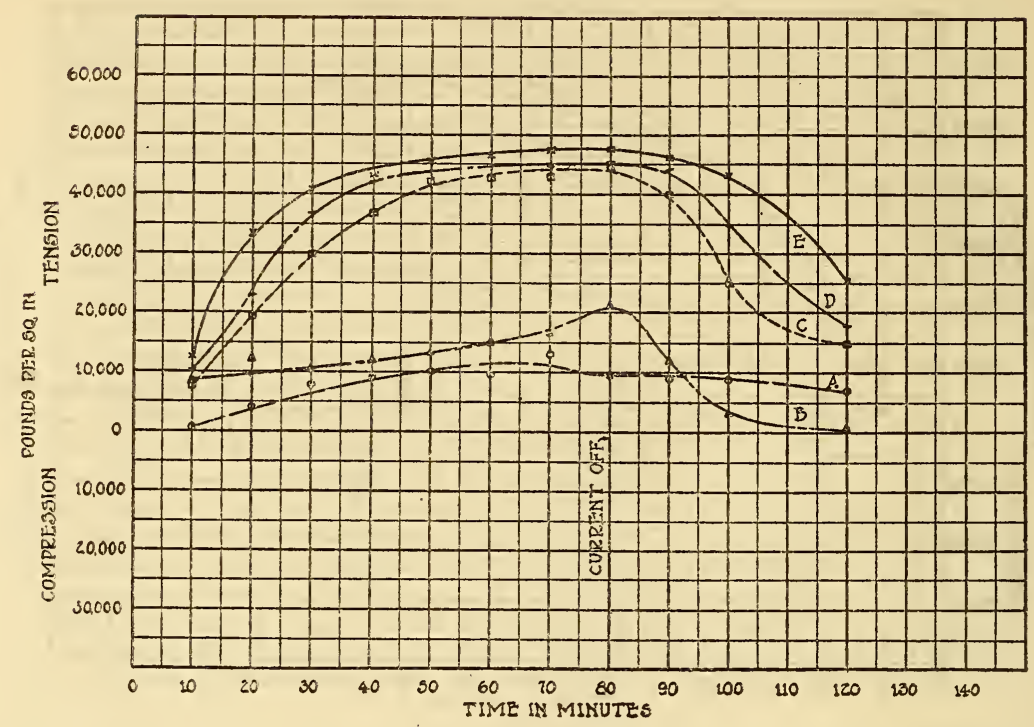

FIG. 2I.-Stress-time curves showing average stresses developed on face of all worn wheels of manufacturer $W$.

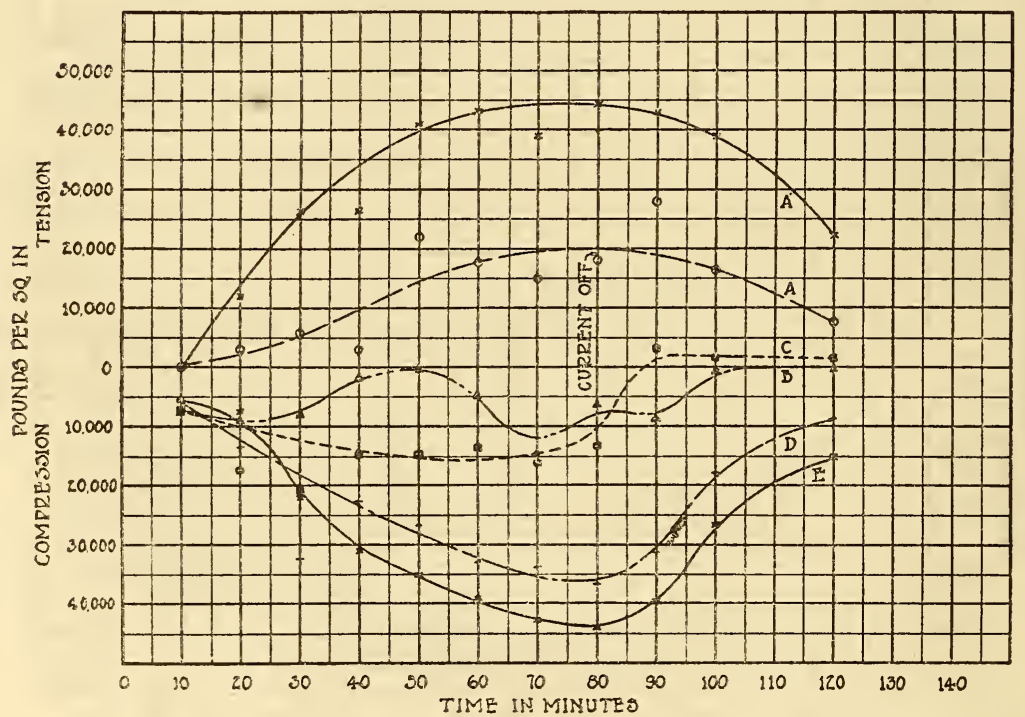

FIG. 22.-Stress-time curves showing average stresses developed on back of a worn wheel of manufaciurer $W$. 


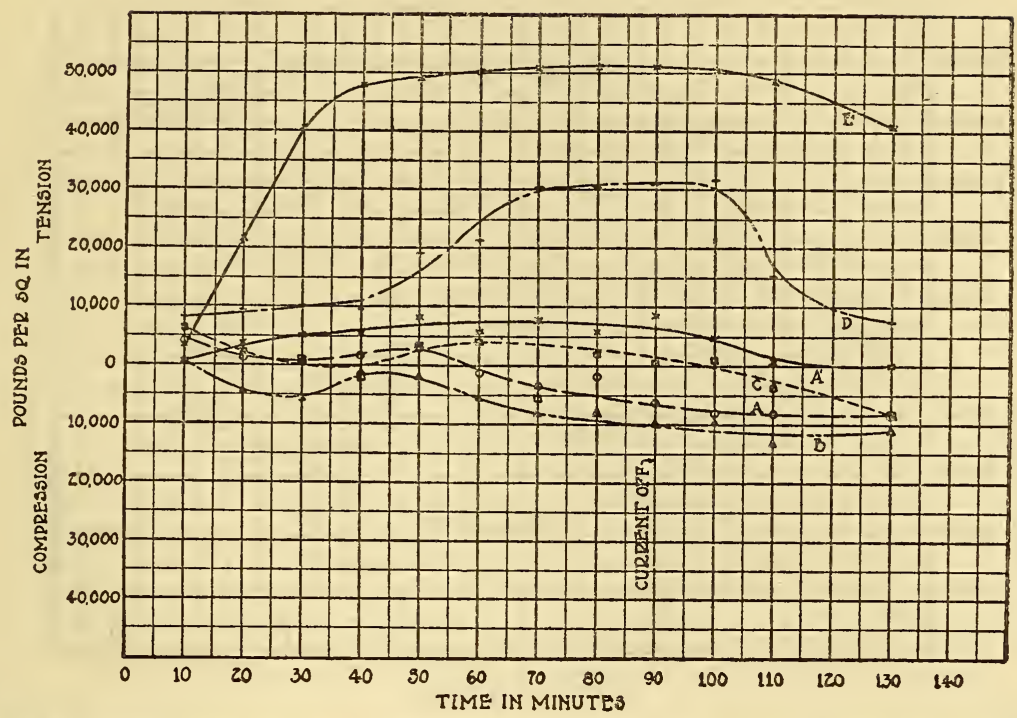

FIG. 23.-Stress-time curves showing average stresses developed on a face crest of all new wheels of manufacturer $X$.

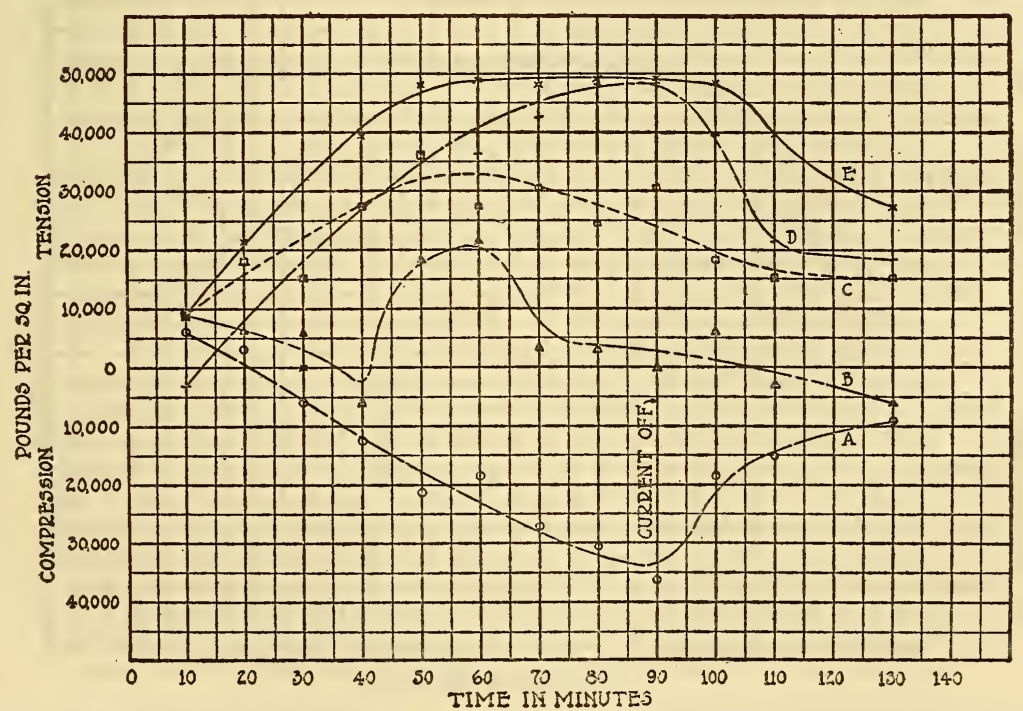

FIG. 24.-Stress-time curves showing average stresses developed in a face hollow of a new wheel of manufacturer $X$. 


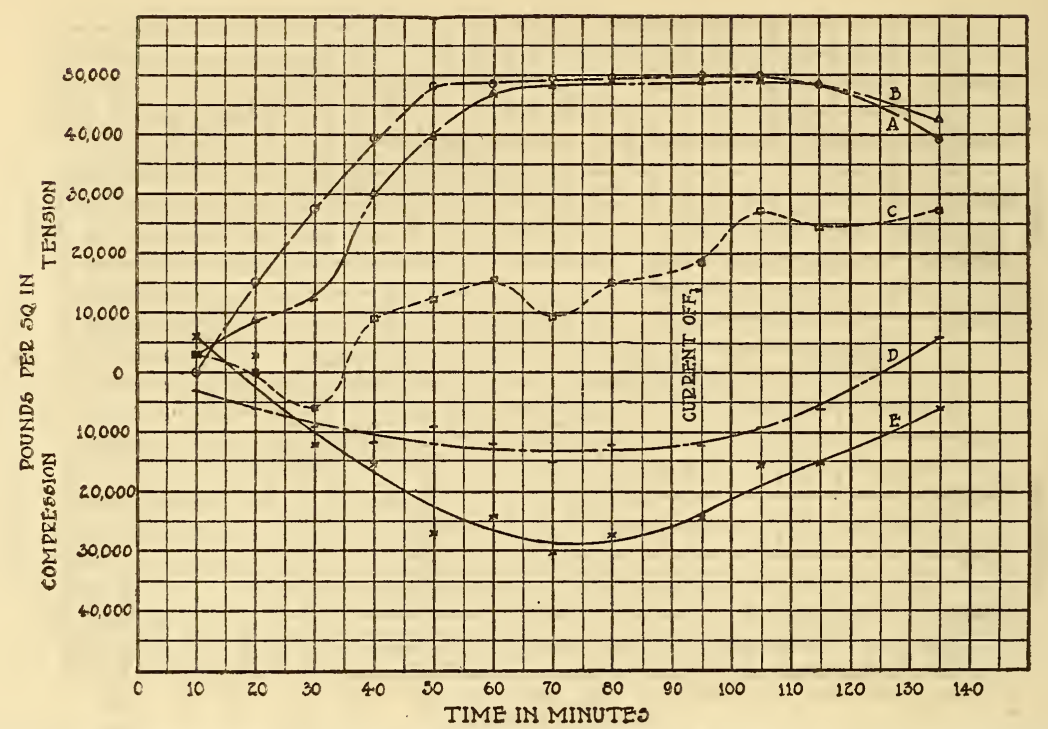

Fig. 25.-Stress-time curves showing average stresses developed on a back crest of a new wheel of manufacturer $X$.

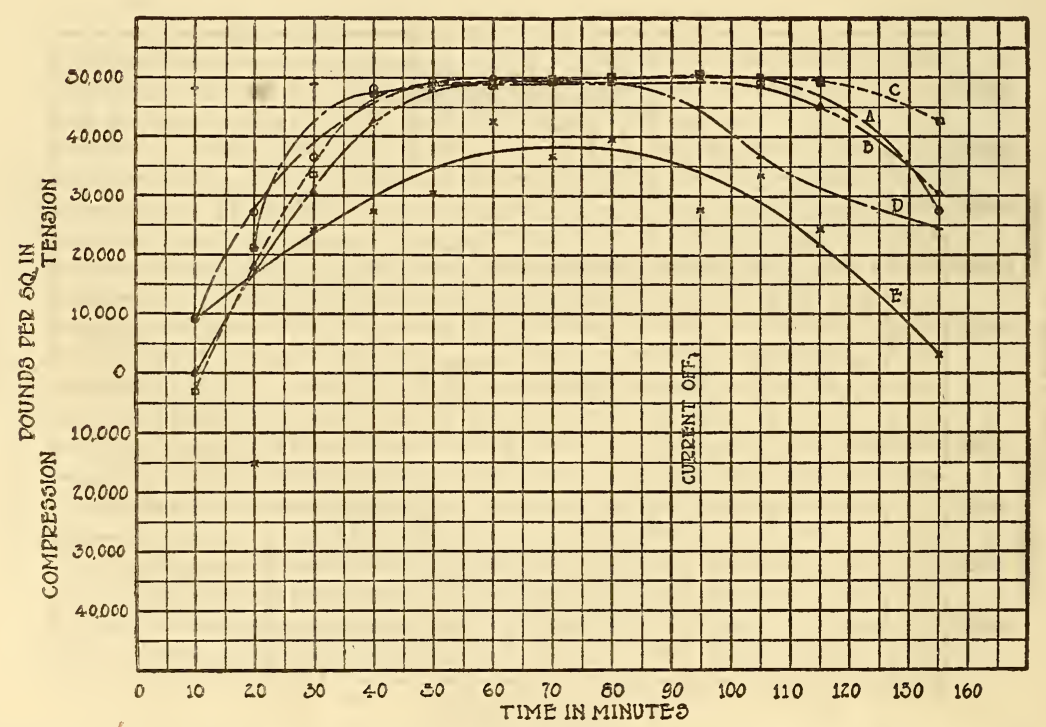

Fig. 26.-Stress-time curves showing average stresses developed in a back hollow of a new wheel of manufacturer $X$. 


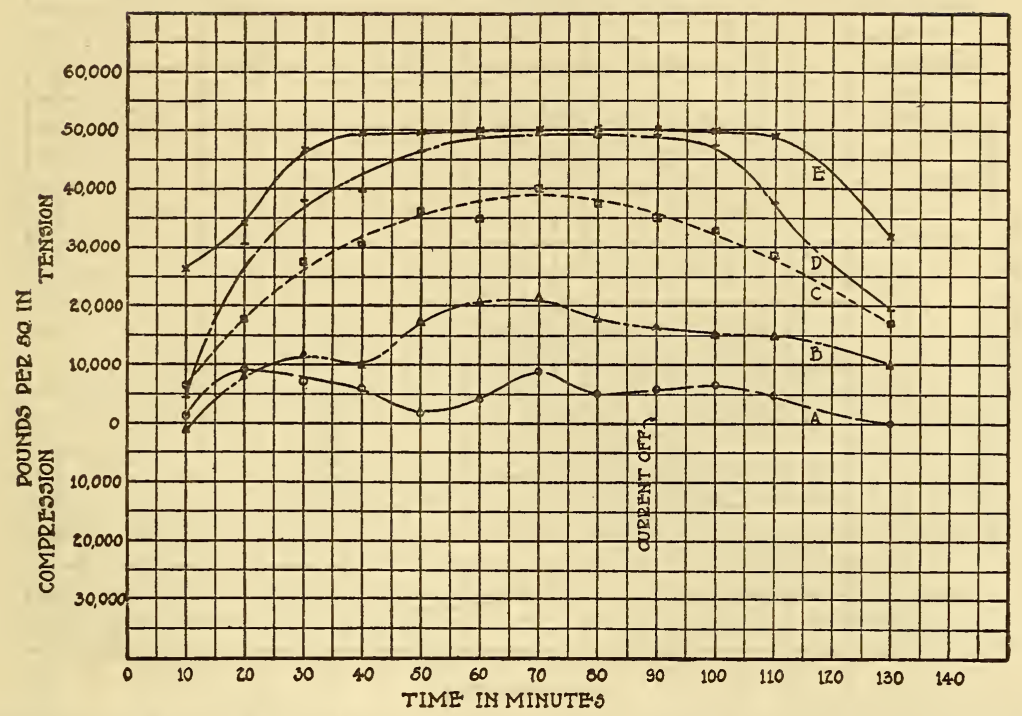

FIG. 27.-Stress-time curves showing average stresses developed on a front crest of all worn wheels of manufacturer $X$.

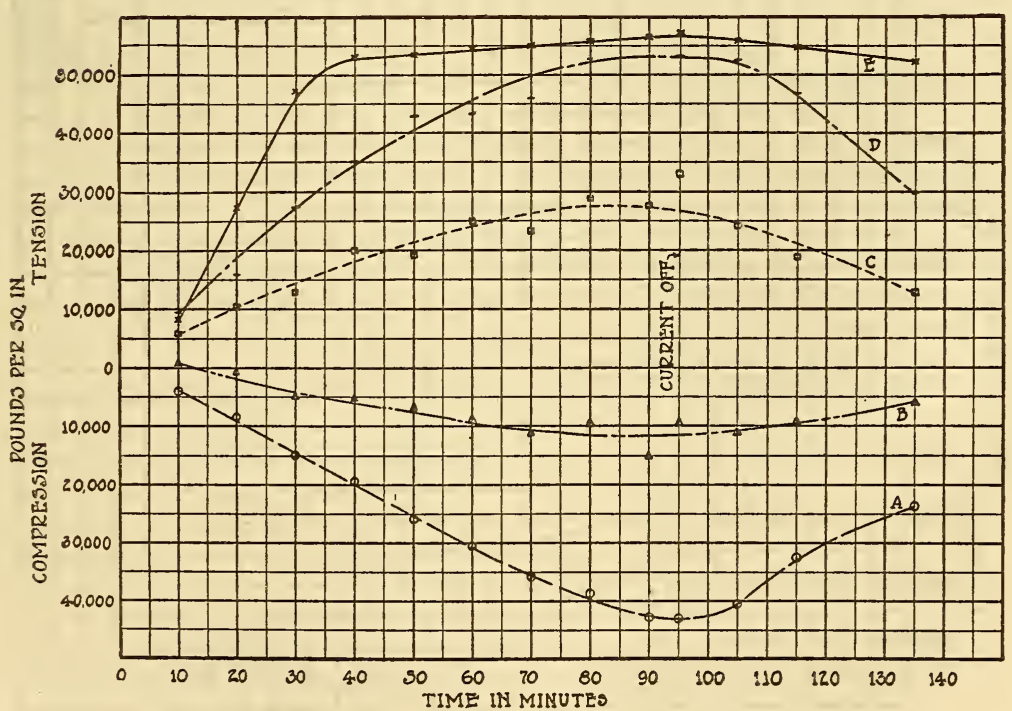

FIG. 28.-Stress-time curves showing average stresses developed on face of all new wheels of manufacturer $Y$. 


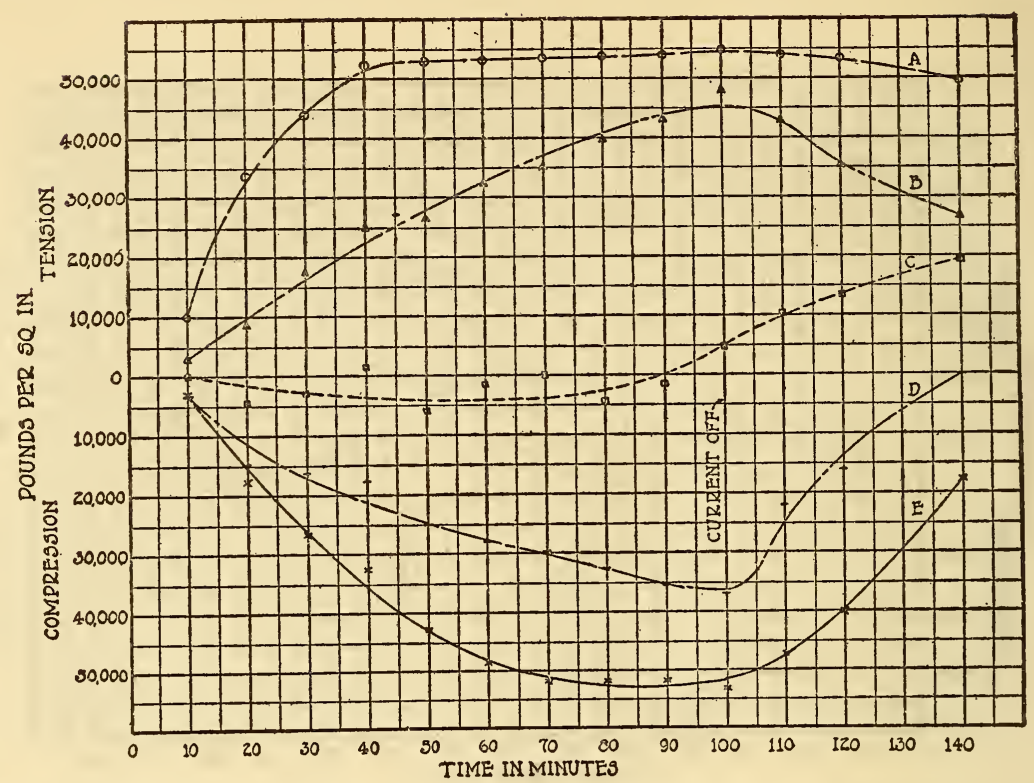

FIG. 29.-Stress-time curves showing average stresses developed on back of a new wheel of manufacturer $Y$.

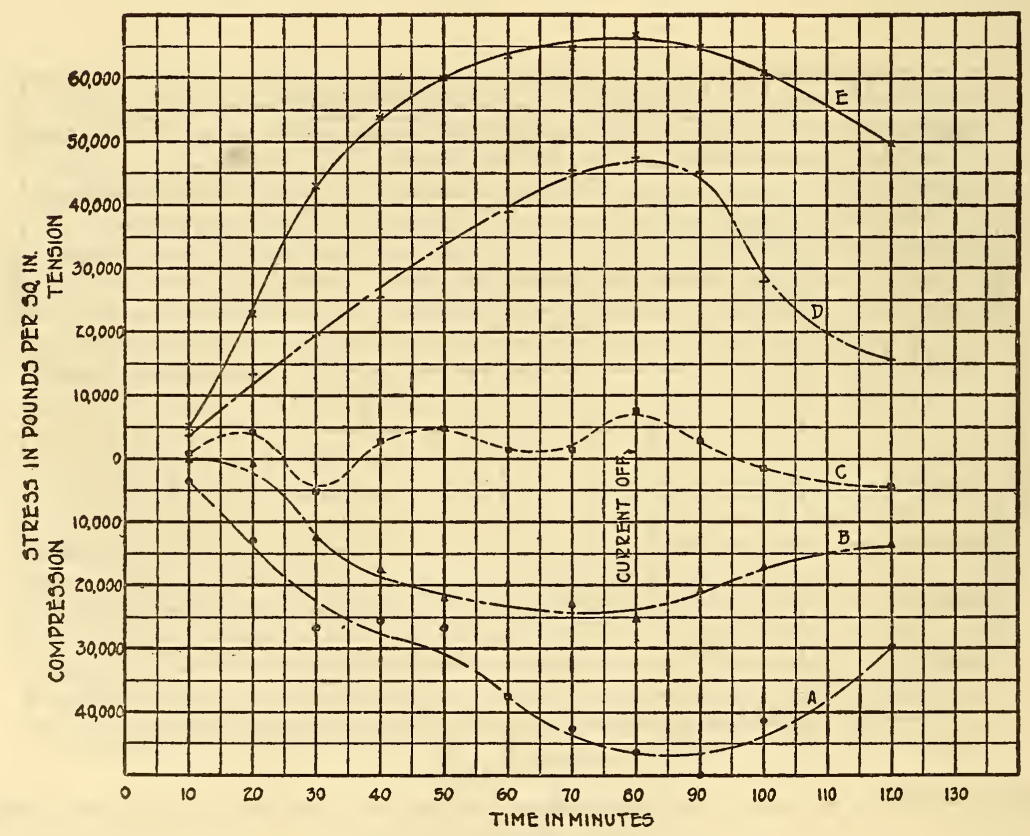

FIG. 30.-Stress-time curves showing average stresses developed on face of a new wheel of manufacturer $Z$. 


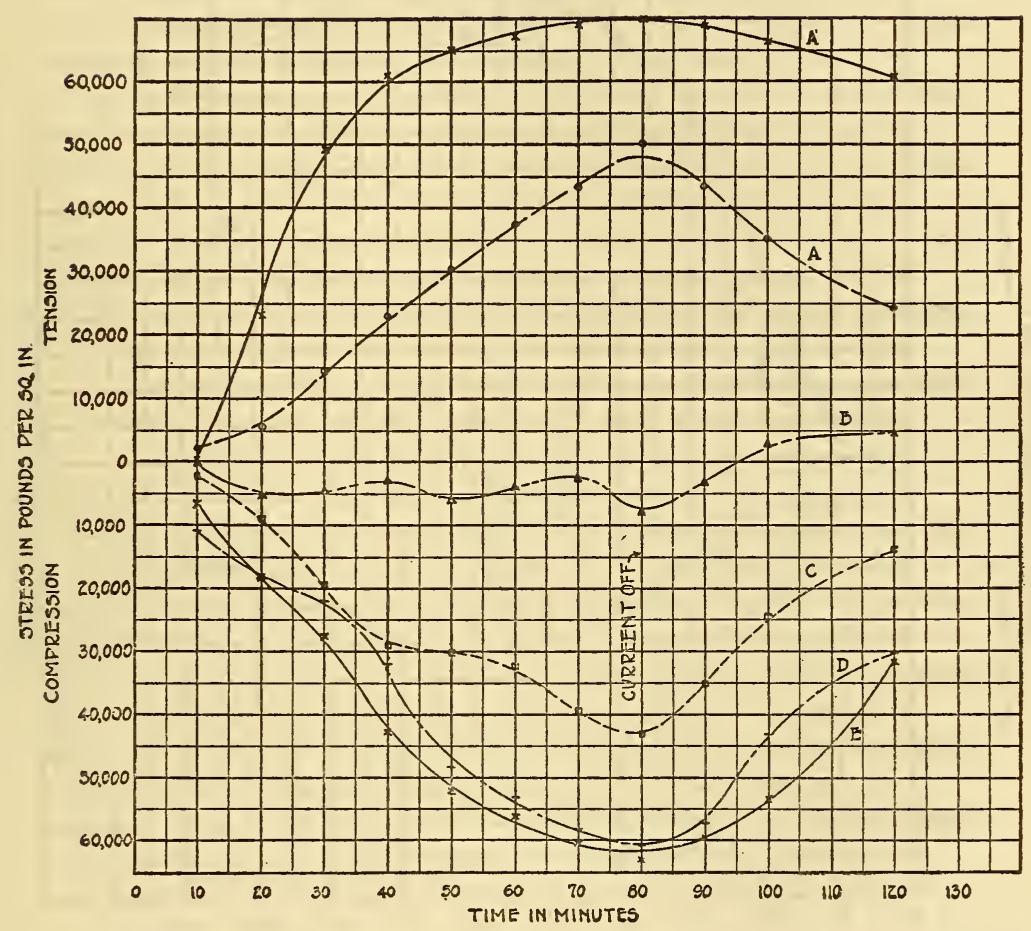

FIG 3r.-Stress-time curves showing average stresses developed on back of a new wheel of manufacturer $Z$. 


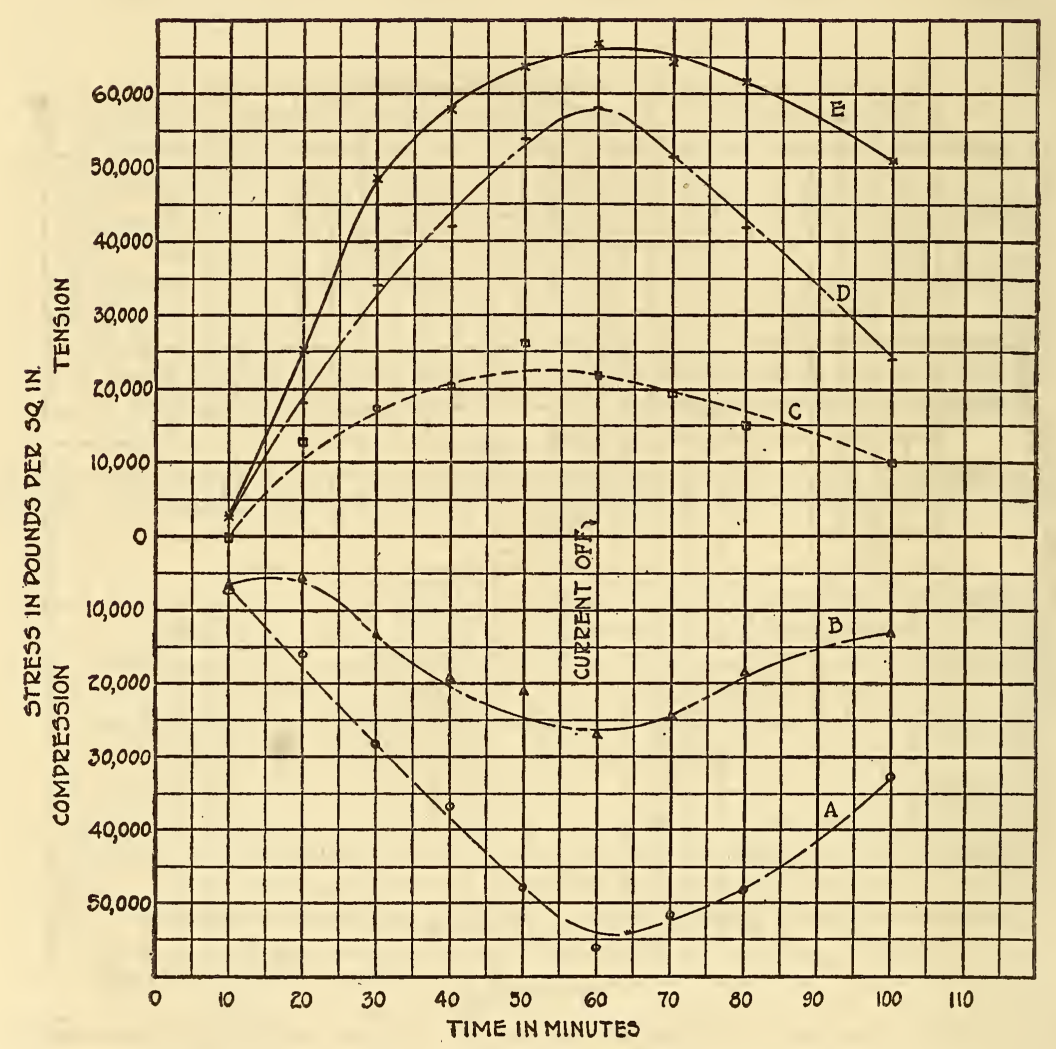

FIG. 32.-Stress-time curves showing average stresses developed on face of a new thin-plate wheel of manufacturer $Z$. 


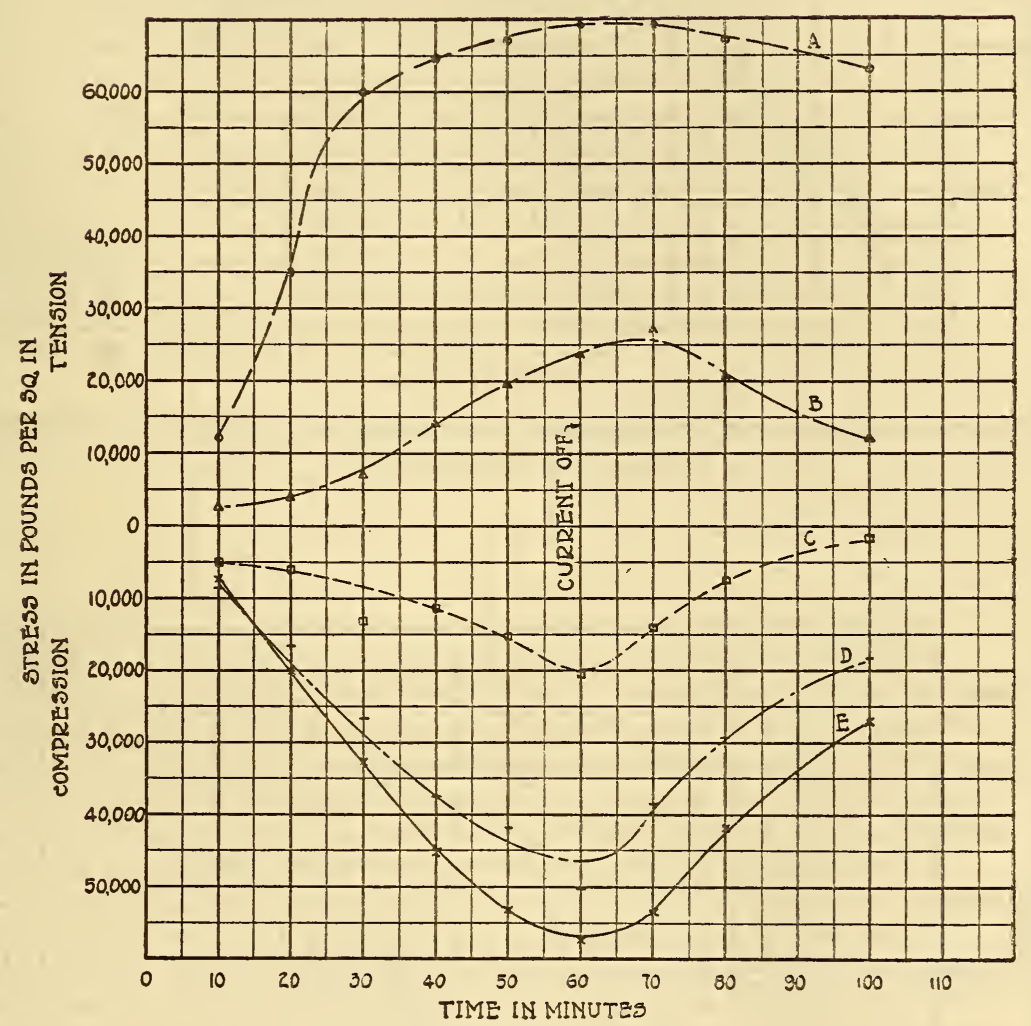

FIG. 33.-Stress-time curves showing average stresses developed on back of a new thin-plate wheel of manufacturer $Z$. 


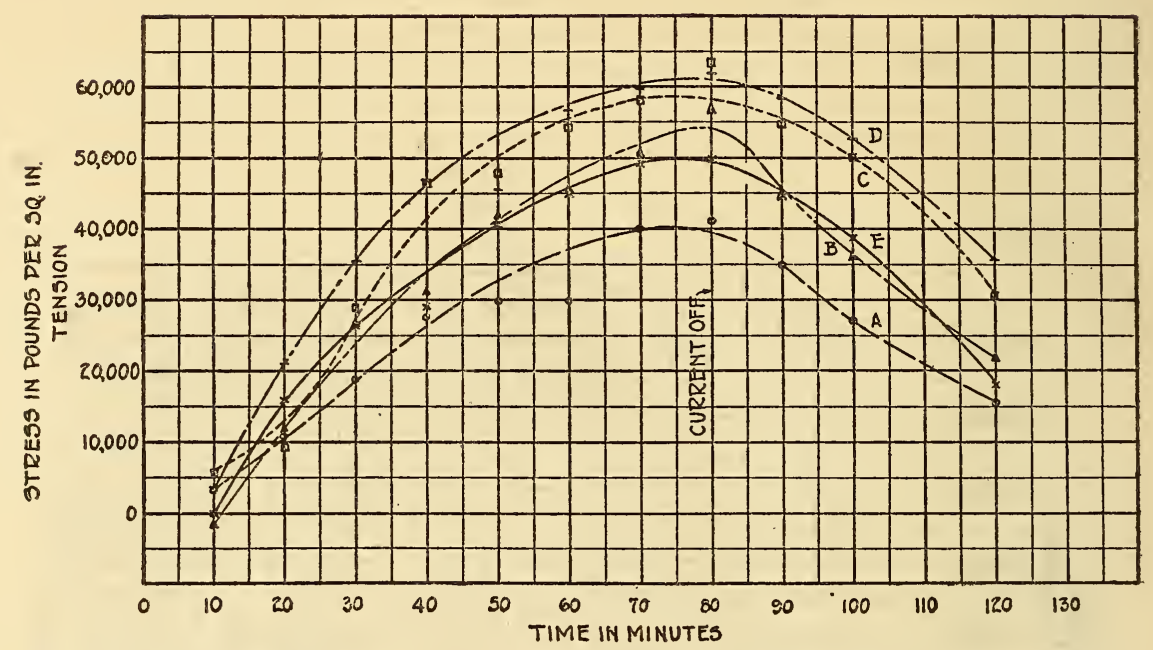

FIG. 34.-Stress-time curves showing average stresses developed on front of a new straightplate wheel of manufacturer $Z$.

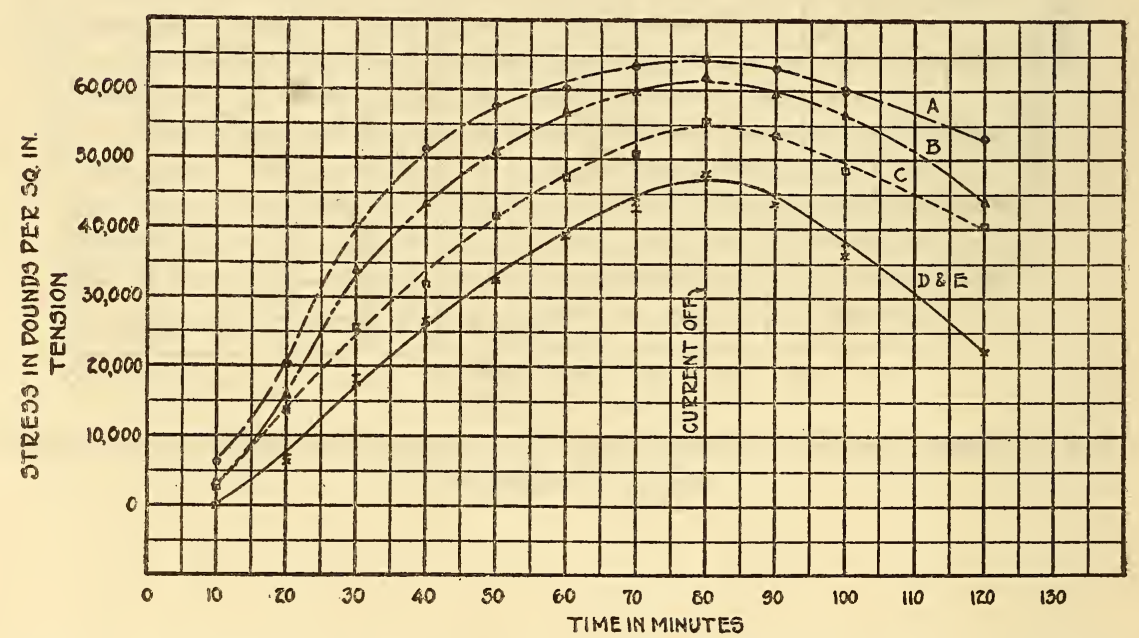

FIG. 35.-Stress-time curves showing average stresses developed on back of a new straightplate wheel of manufacturer $Z$. 


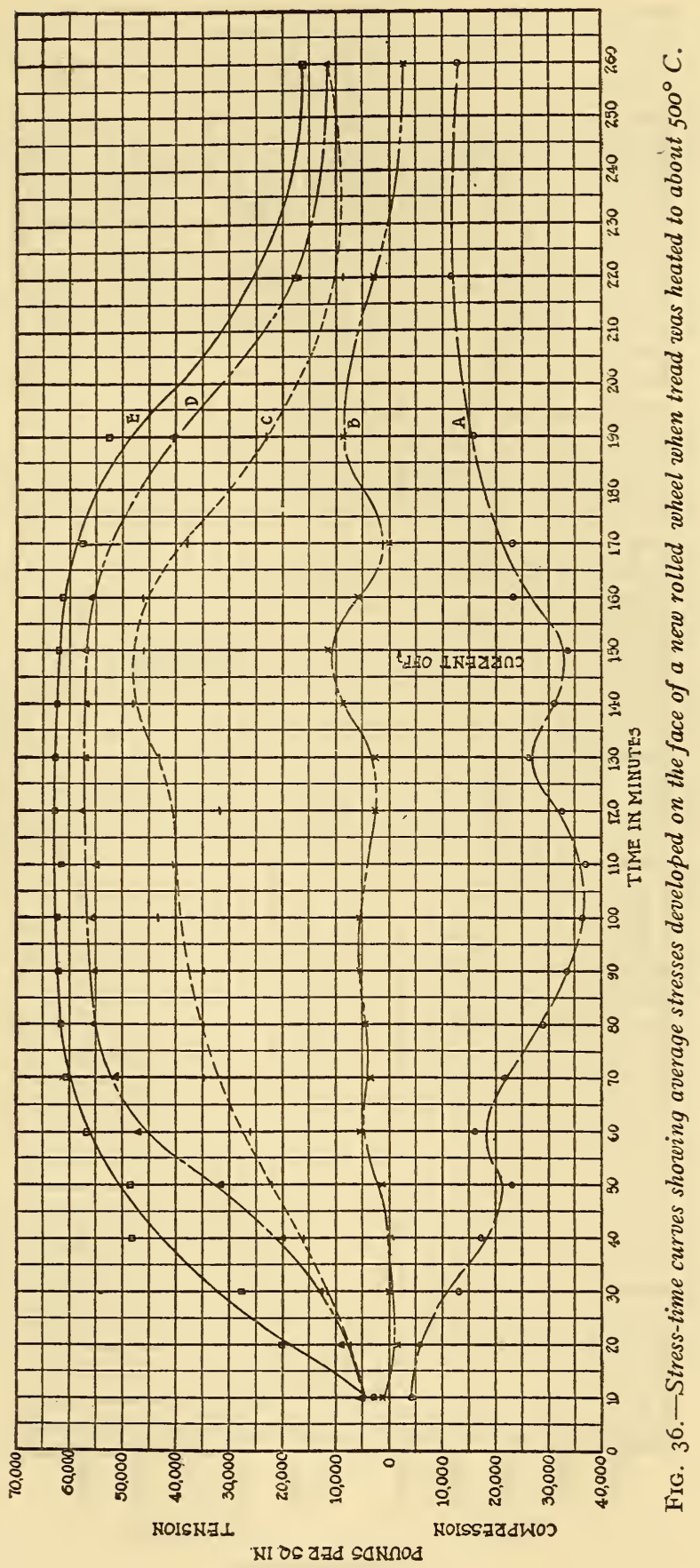




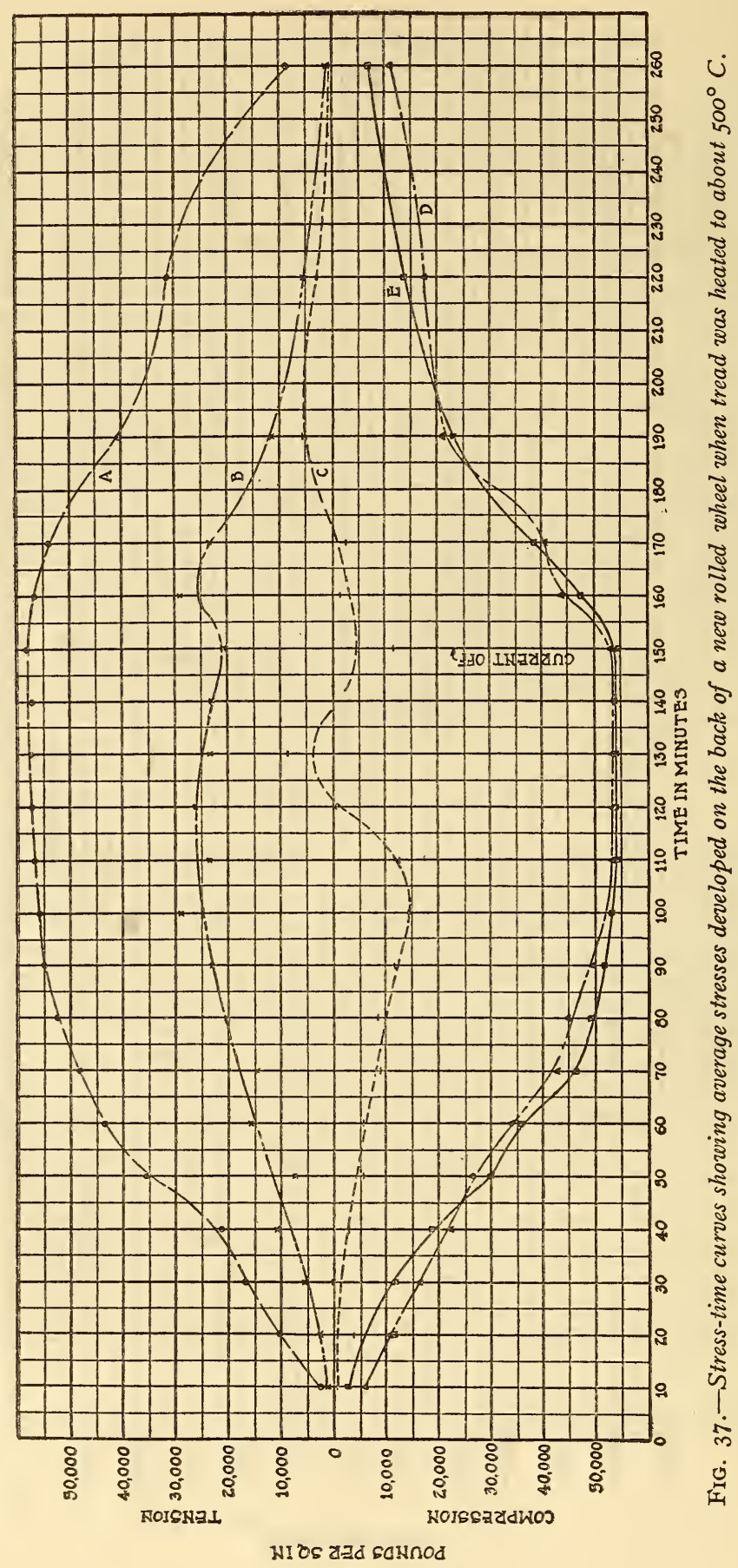




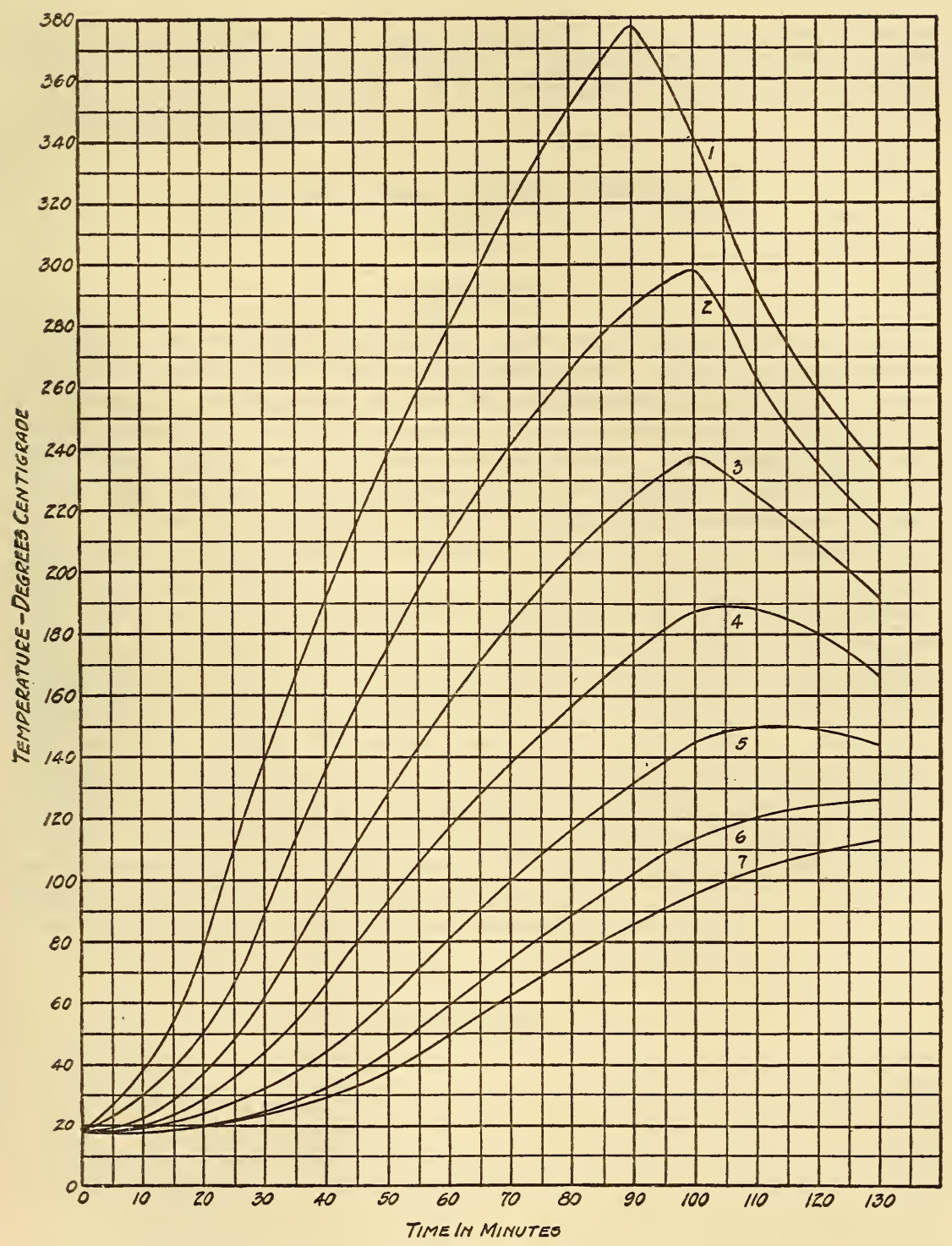

FIG. 38.-Temperature-time curves of a typical test on a rolled wheel. 